\title{
Stekende insecten rondom de Westelijke Langstraat
}

\author{
Risico-analyse
}

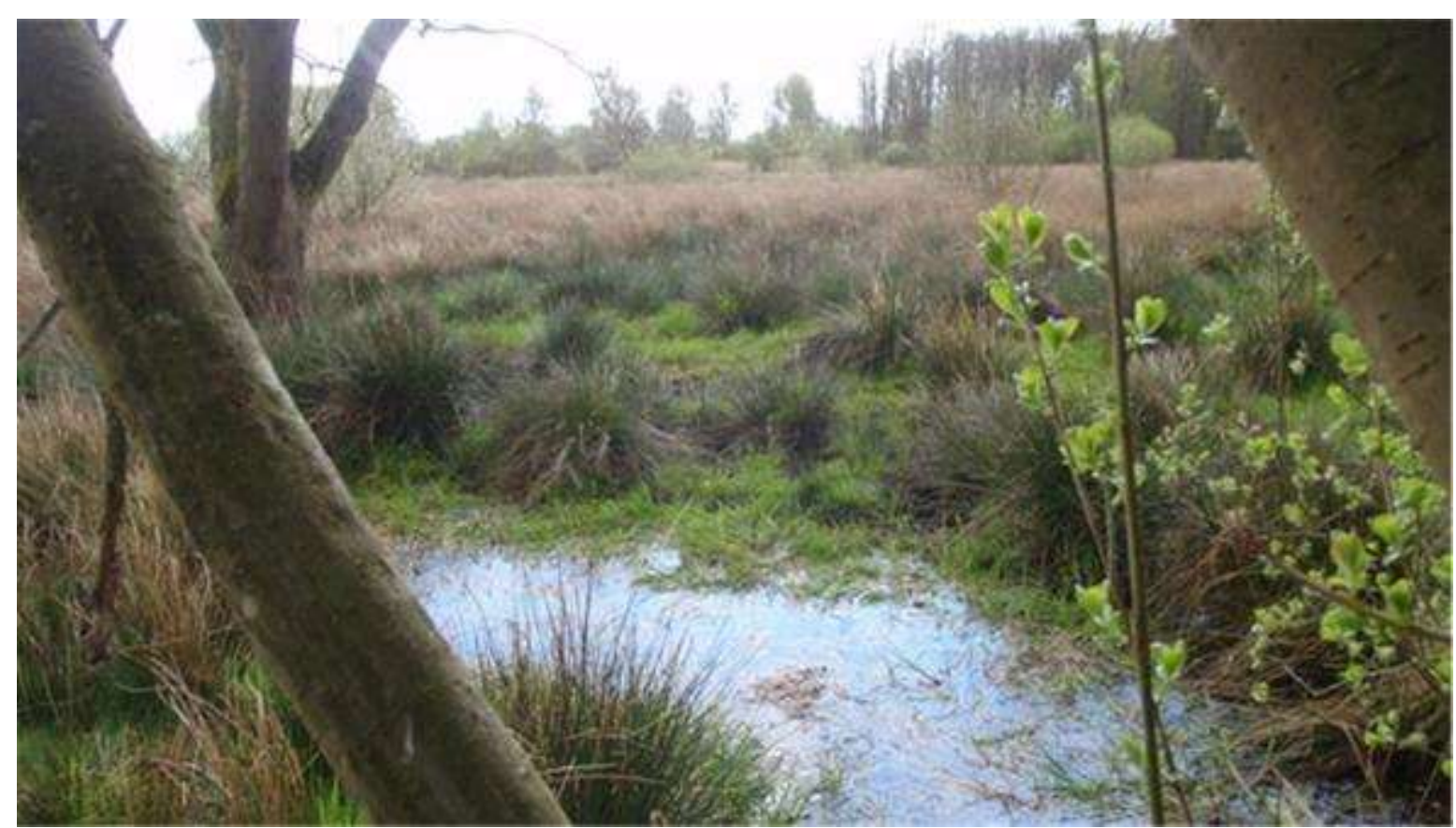

Piet F.M. Verdonschot 


\section{Auteurs}

Piet F.M. Verdonschot (correspondentie: piet.verdonschot@wur.nI)

\section{Opdrachtgever}

Provincie Noord-Brabant

\section{Projectgroep}

Maartje van Moll (Provincie Noord-Brabant)

\section{Wijze van citeren}

Verdonschot P.F.M. (2019) Stekende insecten rondom de Westelijke Langstraat. Risicoanalyse. Notitie Zoetwaterecosystemen, Wageningen Environmental Research, Wageningen UR, Wageningen. 23 pp.

\section{Trefwoorden}

steekmuggen, knutten, N2000, herinrichting, natte natuur

\section{Beeldmateriaal}

Piet Verdonschot

DOI: https://doi.org/10.18174/509290

ISBN: 978-94-6395-246-0

Dit project is uitgevoerd in opdracht van de Provincie Noord-Brabant.

(c) 2019 Zoetwaterecosystemen, Wageningen Environmental Research

- Overname, verveelvoudiging of openbaarmaking van deze uitgave is toegestaan mits met duidelijke bronvermelding.

- Overname, verveelvoudiging of openbaarmaking is niet toegestaan voor commerciële doeleinden en/of geldelijk gewin.

- Overname, verveelvoudiging of openbaarmaking is niet toegestaan voor die gedeelten van deze uitgave waarvan duidelijk is dat de auteursrechten liggen bij derden en/of zijn voorbehouden.

Wageningen Environmental Research aanvaardt geen aansprakelijkheid voor eventuele schade voortvloeiend uit het gebruik van de resultaten van dit onderzoek of de toepassing van de adviezen.

\section{Notitie Zoetwaterecosystemen, Wageningen Environmental Research}

Wageningen, augustus 2019 


\section{Inhoud}

Samenvatting $\quad 5$

1 Inleiding en doel 6

2 Methode 8

3 Resultaten quickscan 9

3.1 Algemene kenmerken van het studiegebied: huidige situatie 9

3.2 Kenmerken van het studiegebied: gewenste situatie 11

$\begin{array}{ll}3.3 & \text { Ontwikkeling van larven van stekende insecten } \\ 3.4\end{array}$

3.4 Verspreiding van volwassen stekende insecten 22

$\begin{array}{lll}3.5 & \text { Initiële fase na aanleg } & 23\end{array}$

4 Aanvullende maatregelen $\quad 24$

4.1 Mogelijke aandachtspunten en aanvullende maatregelen $\quad 24$

$\begin{array}{lll}4.2 & \text { Beheer } & 24\end{array}$

5 Discussie en conclusies $\quad 25$

$\begin{array}{llr}6 & \text { Literatuur } & 27\end{array}$ 


\section{Samenvatting}

Deze studie had als doel het uitvoeren van een risico-analyse op de kans op het voorkomen van stekende insecten in de toekomstige situatie in en rondom de Westelijke Langstraat. Daarnaast was het opstellen van een advies voor het voorkomen van overlast van stekende insecten door aanvullende maatregelen op basis van de voorgenomen herinrichting en beheer een tweede doel.

De te ontwikkelen natuur in de Westelijke Langstraat is vooral afhankelijk van hogere grondwaterstanden en beperken van de voedselrijkdom. Daarom zijn maatregelen opgenomen om het gebied te vernatten en de voedselrijkdom te verlagen. De vernatting zal sneller worden bereikt dan de verarming. De gestelde doelen vragen ook een stabieler waterpeil waarvan de haalbaarheid op basis van modelberekeningen minder zeker is.

De toekomstige milieu-omstandigheden zijn geanalyseerd op het al dan niet geschikt zijn voor de ontwikkeling van larven van stekende insecten. De resultaten van de risico-analyse geven twee onzekerheden aan. Ten eerste duiden de hydrologische modelresultaten aan dat de peilen meer kunnen gaan fluctueren dan gewenst en het onzeker is of aansluitend op de inrichting met gedetailleerd beheer van de peilen de gewenste omstandigheden wel gehaald gaan worden, vooral dat er een kans in het voorjaar op water op maaiveld bestaat door plaatselijk te hoog peil. Ten tweede is onvoldoende voedselarm water voorhanden en kan voedselverrijking optreden door toevoer van voedselrijk grondwater. Hierbij leidt plaatselijk afgraven verder tot situaties waarin stekende insecten juist de eerste jaren uitstekende broedplaatsen kunnen vinden.

De conclusie luidt dat de kans dat het studiegebied Westelijke Langstraat met de voorgenomen herinrichting leidt tot overlast van stekende insecten aannemelijk groot is tenzij er in wordt geslaagd door peilbeheer en watersturing een hydrologisch stabiele situatie te laten ontstaan waarbij kwel met voedselarmer water de boventoon voert en de waterpeilen in zomer (zomerpeil) en vooral in winter (winterpeil) weinig gaan fluctueren. Daarnaast kan in de $1^{\mathrm{e}}$ jaren meer overlast optreden, totdat ecosysteem weer ontwikkeld is, waarbij natuurlijke predatoren van stekende insecten algemener zullen voorkomen.

Monitoring in de eerste jaren na inrichting zou de ontwikkeling van stekende insecten kunnen vastleggen en helpen bij het gedetailleerd waterbeheer doordat bij larvenontwikkeling snel kan worden opgetreden.

Omdat de afstand tot bewoning zo klein is moet ervoor worden gezorgd dat de aantallen zich ontwikkelende larven van stekende insecten zo laag mogelijk blijft. Daarom is aandacht nodig voor:

- een gedetailleerd peilbeheer dat de hydrologische dynamiek verminderd en dat water op maaiveld in de loop van april over grotere oppervlakken is verdwenen,

- het zo min mogelijk inlaten van voedselrijk water,

- het verkrijgen van draagkracht voor volwassen stekende insecten in het gebied zelf in de vorm van bosschages en dat barrières aanwezig zijn tussen broedgebieden en bewoning middels vlakken met zeer korte vegetatie of open water,

- gericht beheer waarmee de aantallen stekende insecten nog verder verminderen door maaien van barrières, niet of slechts zeer ondiep plaggen om te natte gebieden te voorkomen, en niet begrazen. 


\section{Inleiding en doel}

De provincie Noord-Brabant heeft Wageningen Environmental Research (WEnR) verzocht om te analyseren wat de risico's zijn op overlast van stekende insecten in de omgeving van de Westelijke Langstraat na de uitvoering van de maatregelen zoals beschreven in de PAS; hierna aangeduid als studiegebied (Figuur 1.1). Dit naar aanleiding van de zorg geuit door omwonenden.

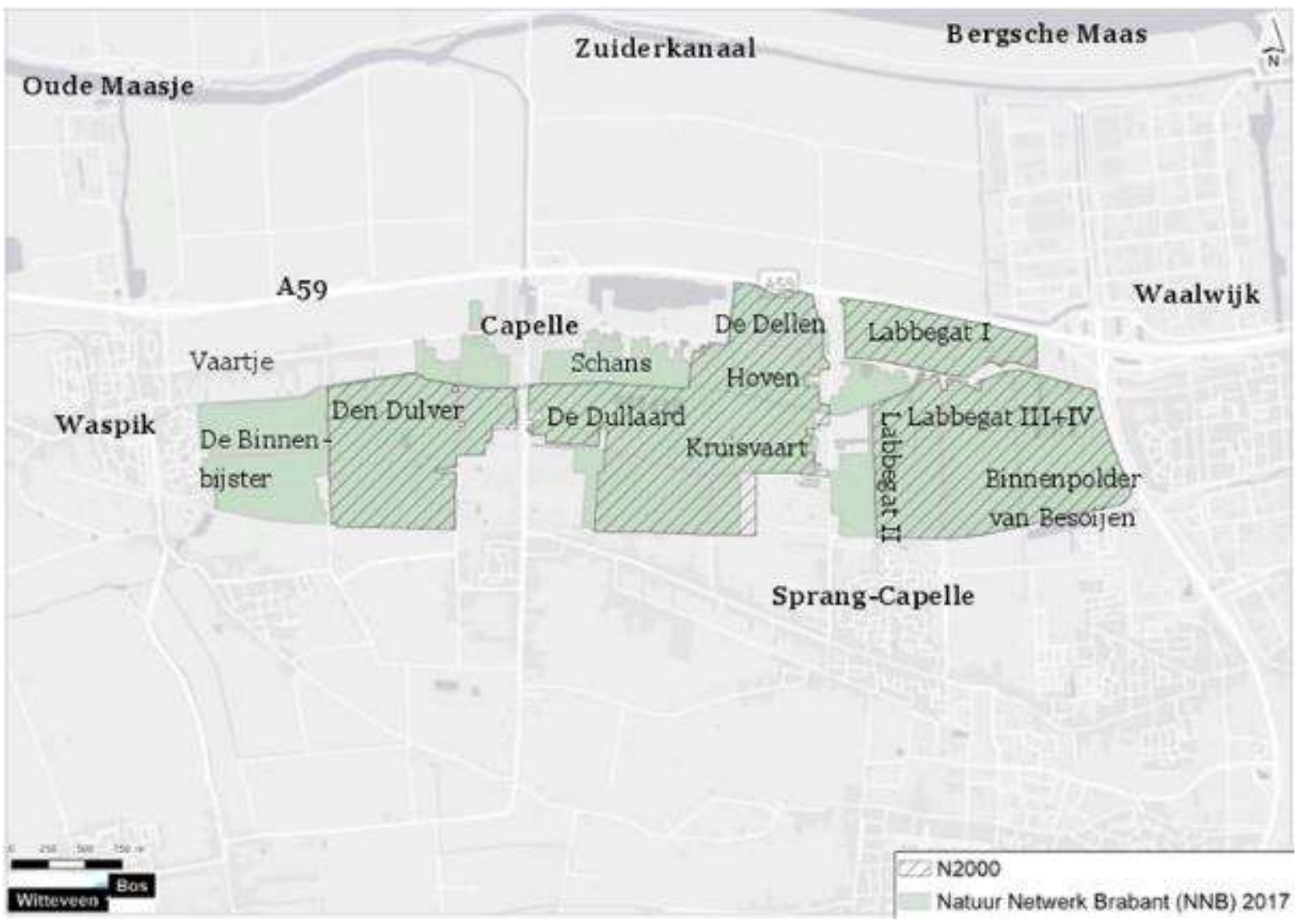

Figuur 1.1: Begrenzing van de Westelijke Langstraat als Natura 2000-gebied en Natuurnetwerk Brabant (NNB) (uit Provincie Noord-Brabant 2017).

De Westelijke Langstraat omvatte tot ver in de middeleeuwen veenmoerassen in kwelders en lagunes achter strandwallen. De daarna groeiende menselijke invloed is zichtbaar in de vorm van dijken, kaden, afwateringssloten en bebouwing; er ontstond een slagenlandschap. Het landgebruik bestond lange tijd uit turfwinning, ontginningen, hooilanden en industrie.

Omdat verdroging en stikstofdepositie de natuur in de Westelijke Langstraat aantasten is besloten 600 hectare (natuur)gebied opnieuw in te richten en natuur te ontwikkelen. Hiervoor worden ook landbouwpercelen omgevormd naar natuur.

Het doel is om de Westelijke Langstraat om te vormen tot natuurgebied met als referentie het cultuurlandschap van rond 1900. Dit landschap omvatte blauwgraslanden, trilvenen en kalkmoerassen.

Het studiegebied Westelijke Langstraat is opgedeeld in deelgebieden. Deze deelgebieden zijn De Binnenbijster, Den Dulver, Tolweg Noord, Kwekel, De Schans, De Dullaard, De Dellen, De Hoven, Kruisvaart, Hogevaart, Zuidewijn, Labbegat, Labbegat II, Labbegat III, Labbegat IV, Landzicht en Binnenpolder van Besoijen (Figuur 1.2). 


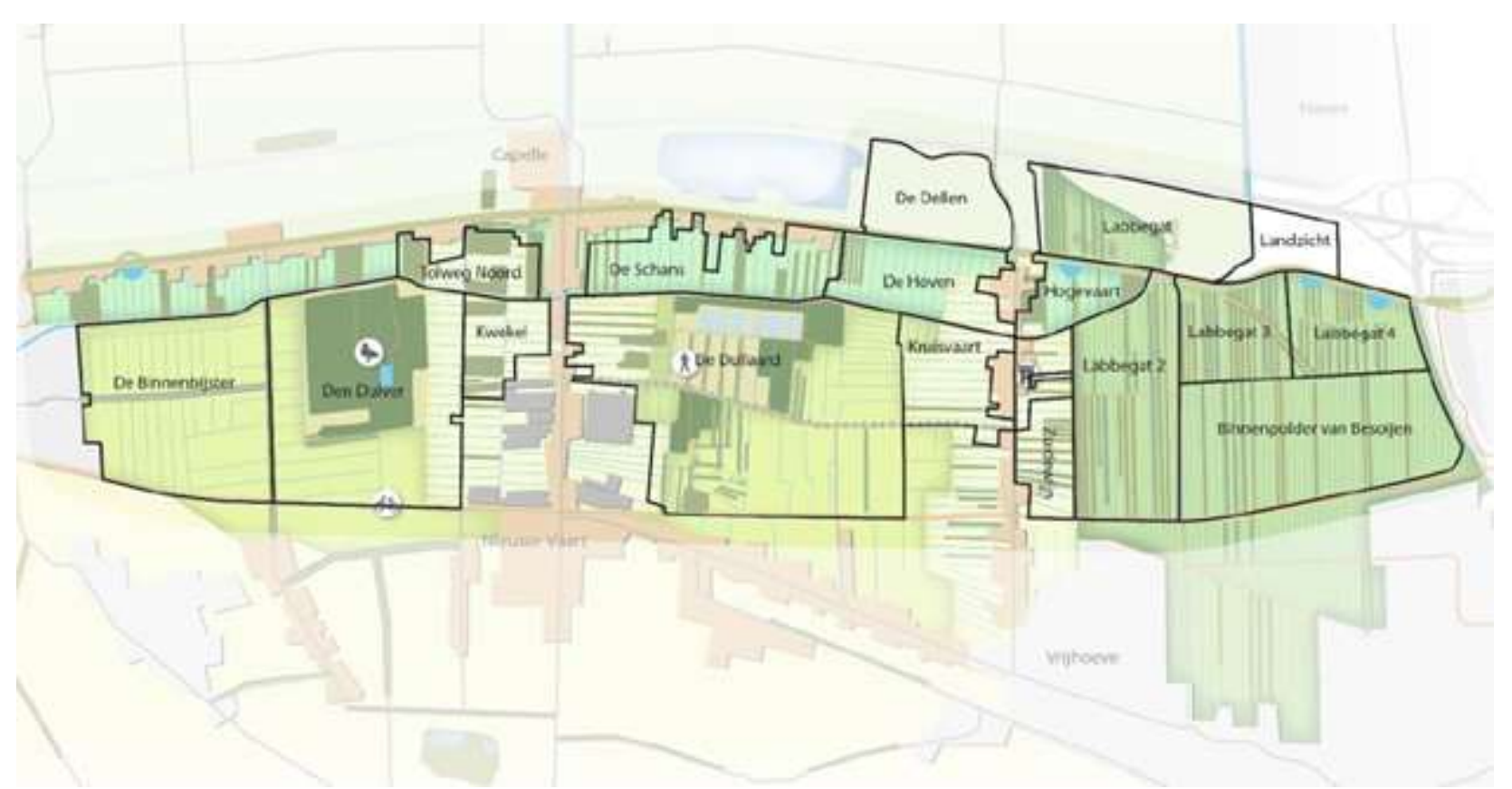

Figuur 1.2: De deelgebieden in de Westelijke Langstraat.

Het Natura 2000-gebied de Westelijke Langstraat is opgenomen in de Programmatische Aanpak Stikstof 2015-2021. Het doel voor 2027 is de natuuropgave om de aanwezige habitattypen in het Natura 2000-gebied uit te breiden en te verbeteren en de ambitie van de provincie om het Natuurnetwerk (NNB) te realiseren. In totaal wordt bescherming en ontwikkeling nagestreefd voor tien N2000 habitattypen, twee Habitatrichtlijnsoorten (grote en kleine modderkruiper) en diverse rode lijstsoorten genoemd in de leefgebiedenbenadering van de provincie Noord-Brabant.

Het hoofddoel van het project Westelijke Langstraat is het behoud en de ontwikkeling van natuur. Daarbij gaat het met name om zeldzame, grondwaterafhankelijke natuur gekoppeld aan schrale bodems en voedselarm tot matig voedselrijk, basenrijk grondwater.

De achteruitgang van de kwelafhankelijke habitattypen blauwgraslanden (H6410), trilvenen $(H 7140 A)$ en kalkmoerassen (H7230) dient te worden gestopt en uitbreiding gerealiseerd.

Het doel van deze studie is tweeledig:

1. Het uitvoeren van een risico-analyse op de kans op het voorkomen van stekende insecten in de toekomstige situatie van de Westelijke Langstraat.

2. Het opstellen van een advies voor het vóórkomen van overlast van stekende insecten door aanvullende maatregelen op basis van de voorgenomen herinrichting en beheer. 


\section{Methode}

De quickscan risico-analyse van de omgeving van de Westelijke Langstraat op overlast door stekende insecten na uitvoering van de maatregelen is gebaseerd op de methode beschreven in de 'Leidraad Risicomanagement Overlast Steekmuggen en Knutten' (Verdonschot \& Besse-Lototskaya, 2012). De methode beschreven in de Leidraad maakt gebruik van kennis van stekende insecten, kaarteninformatie en aanvullende informatie uit de verschillende plannen en de MER.

Om de potentieel risicovolle landschapselementen en locaties in het gebied te identificeren zijn de volgende stappen uitgevoerd:

1. Het verzamelen van kaarten. Dit betreft, voor zover beschikbaar, kaarten met hoogte/terreinreliëf, geomorfologie/bodem, hydrologische situatie (droogte/ natheidsindicatie) zoals GHG, GVG, GLG en kwel, landschaps-/natuurtypen met wateren en natte elementen en/of met vegetatie/begroeiing per landschapselement en met bebouwing.

2. Het verzamelen van aanvullende informatie over waterbeweging, (grond)waterstandswisseling (in welke maanden) met bijvoorbeeld een kaart met actuele of modelresultaten. Ook is informatie over voedselrijkdom en beheer verzameld.

Op basis van de kaart- en aanvullende informatie zijn potentiele overlast gevende situaties geduid en zijn adviezen afgeleid over aanvullende beheermaatregelen die ingepast zouden kunnen worden om mogelijke overlast door stekende insecten te beperken. 


\section{Resultaten quickscan}

\subsection{Algemene kenmerken van het studiegebied: huidige situatie}

De quickscan risico-analyse is uitgevoerd voor het studiegebied voor larvale ontwikkeling en de randen van het gebied voor volwassen dieren in een zone van circa $1 \mathrm{~km}$ buiten om het studiegebied. Voor de analyse is gebruik gemaakt van een landschapsecologische systeemanalyse (Witteveen en Bos, bijlage 1 bij MER Westelijke Langstraat, 20192019) en het milieueffectrapport (Nieuwkamer et al. 2019).

De gronden in het zuid(oosten) liggen wat hoger dan in het noord(-westen) (Figuur 3.1), m.a.w. het gebied helt enigszins van zuidoost naar noordwest af.

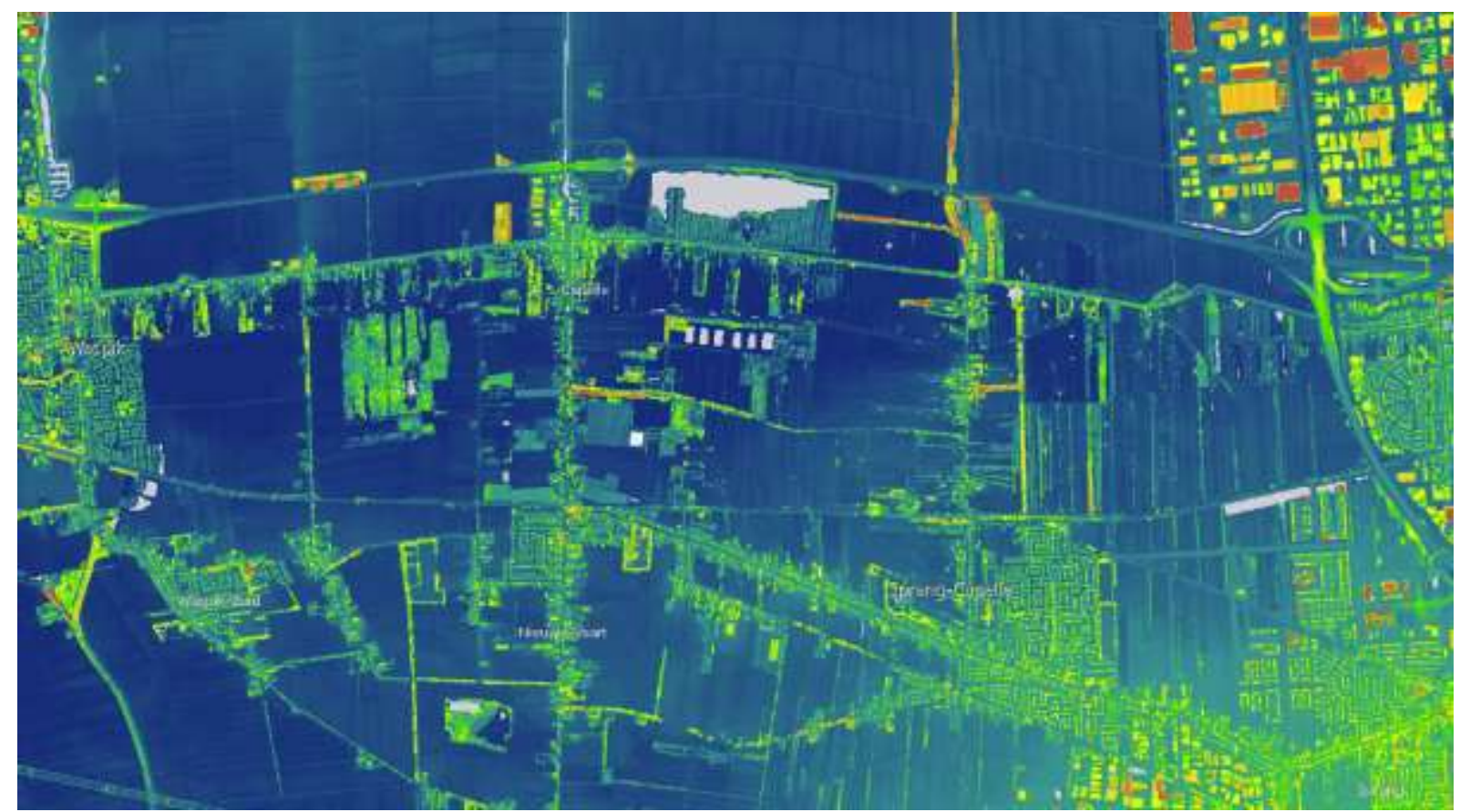

AHN3 ruw - Blauw / Groen / Oranje (Dynamische opmaak)

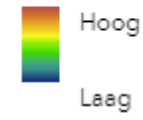

Hoogteprofiel

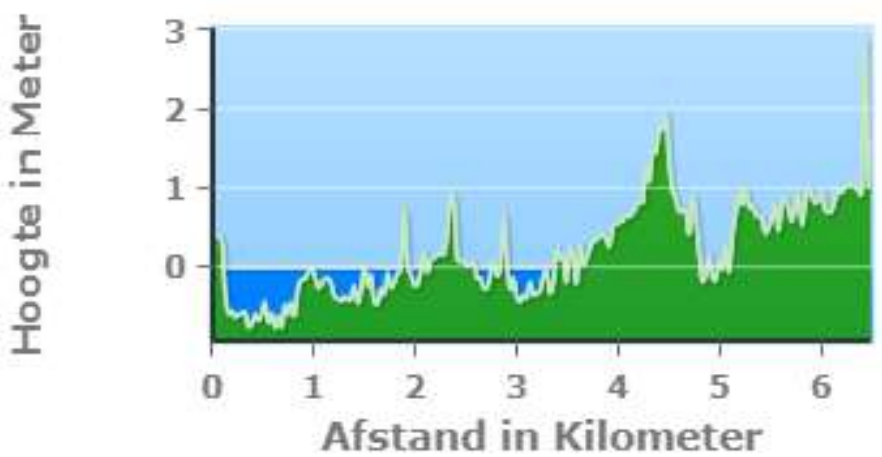

Figuur 3.1: Hoogteligging en hoogteprofiel van het plangebied Westelijke Langstraat (https://ahn.arcgisonline.nl/ahnviewer/).

In het studiegebied bevinden zich in het zuidoosten enkeerdgronden (humusrijke grond) en podzolgronden (ontstaat door in- en uitspoeling in leemarm dekzand) terwijl in de lagere delen zich veen en moerige zandgronden bevinden (Figuur 3.2). De meeste intacte veenbodem is te vinden in Den Dulver en de overige veengronden zijn merendeels afgegraven. Door landbouwkundig gebruik 
en ontwatering zijn de veenresten veraard en door bemesting heeft de bodem overal een hoog fosforgehalte. De ondergrond is fijn tot grof zandig. Ten noorden liggen kleigronden (afzettingen van de Maas) terwijl ten zuiden hogere, infiltrerende zandgronden liggen.

Grote delen van het studiegebied zijn in agrarisch beheer (hooiland, grasland, mais) terwijl de natuurgebieden, beheerd door Staatsbosbeheer, bestaan uit natuurgrasland, rietland, moeras en loofbos met hier en daar poelen en petgaten (Figuur 3.3).

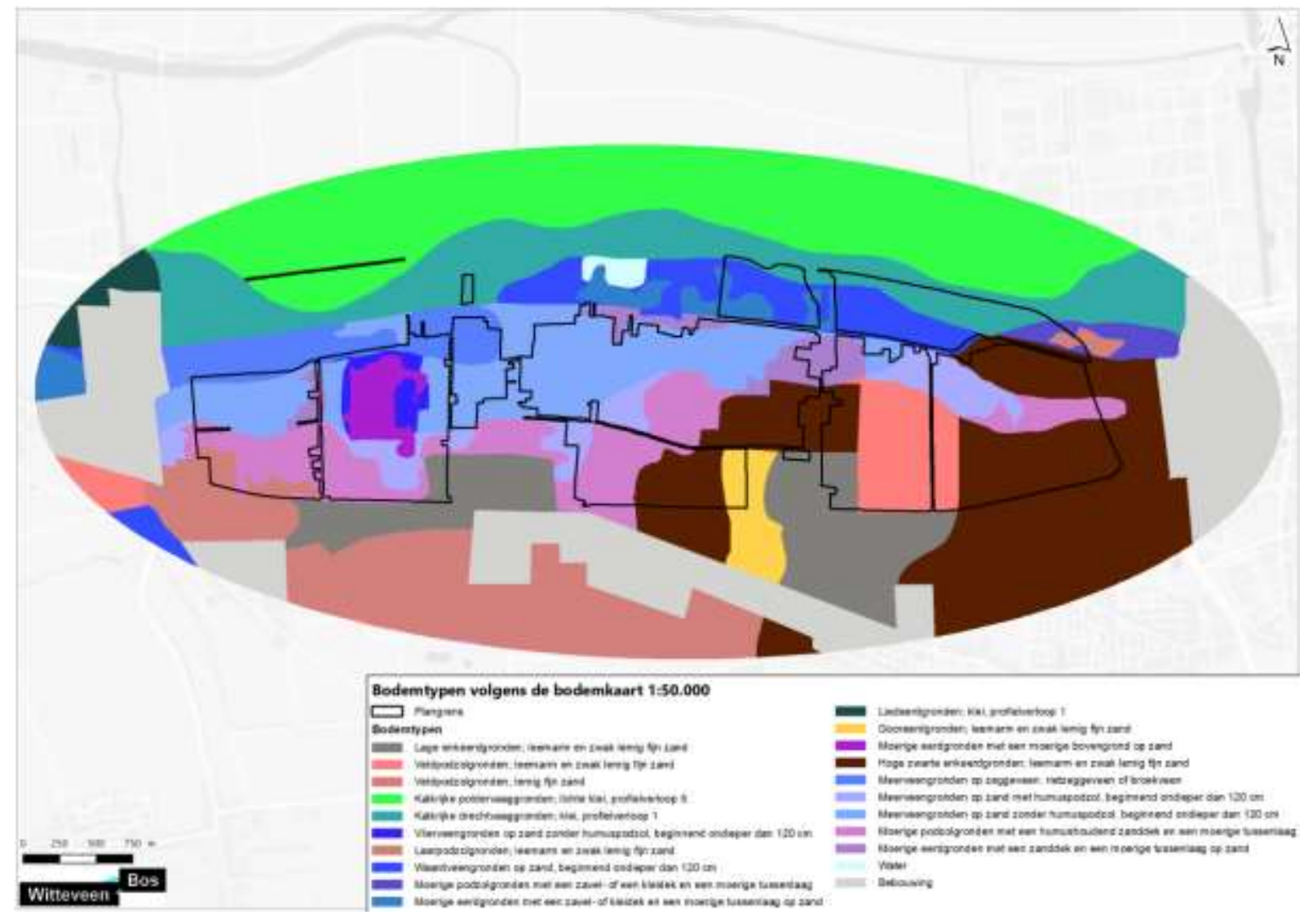

Figuur 3.2: Bodemkaart 1:50.000 (uit Nieuwkamer et al. 2019).

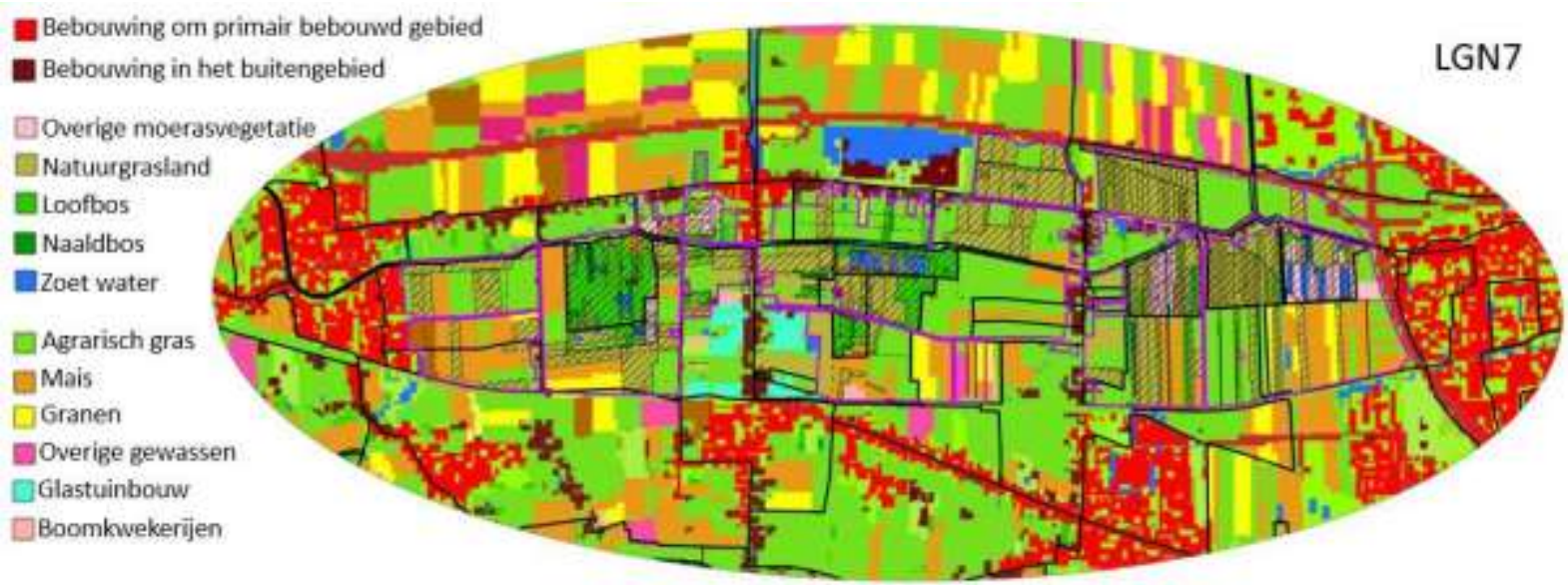

Figuur 3.3: Landgebruik volgens het LGN7. Gearceerde gebieden zij in beheer bij Staatsbosbeheer (uit Nieuwkamer et al. 2019). 
De complexe regionale en lokale grondwaterstromen zorgen voor een menging van typen kwelwater in het studiegebied: van kalkarm tot kalkrijk en van voedselarm tot voedsel verrijkt. Oorzaken hiervan zijn de menging van grondwater uit het tweede en eerste pakket, de toestroom vanuit het noorden en het zijden die mengt in het studiegebied en de lokale hoogteverschillen waardoor lokaal grondwater en regenwater meer of minder invloed uitoefent op de grondwatersamenstelling.

In de huidige situatie is de grondwaterstand GVG $0.3 \mathrm{~m}-\mathrm{mv}$ tot $1.0 \mathrm{~m}-\mathrm{mv}$, behalve in de Binnenbijster, Den Dulver (door waterinlaat), De Schans, Den Dullaard en het Labbegat met GVGs $<0.3 \mathrm{~m}-\mathrm{mv}$. Behalve Den Dulver zijn deze gebieden ook de kwel ontvangende gebieden. Ten zuiden van het studiegebied ligt een groot infiltratiegebied.

De chemische samenstelling van het grondwater kan lokaal verschillen, vaak is sprake van voedingsstoffen en mineralen verrijkt water.

Het oppervlaktewatersysteem is een mozaïek van peilvakken met verschillende steefpeilen. De waterkwaliteit is wisselend afhankelijk van de mate van invloed van (diep) grondwater.

De diepe ontwatering en sterke afwatering hebben het studiegebied verdroogd waardoor veen is veraard en verdwenen en habitats sterk zijn veranderd. Het omgekeerde peil met waterinlaat in de zomer hebben de samenstelling van het oppervlaktewater gewijzigd. Daarnaast speelt de diepe, regionale kwel nauwelijks nog een rol en domineert geïnfiltreerd Maaswater, naast lokaal drainage en regenwater. Dit water is rijk aan voedingsstoffen en macro-ionen. In droge perioden leidt beregening tot sterke grondwaterstandsdaling. Door veraarding van het veen en de verzwakking van de toevoer van kalkrijk grondwater is de bovenste bodem aan het zuurder worden en daalt de buffercapaciteit naast voedselverrijking en verharding.

\subsection{Kenmerken van het studiegebied: gewenste situatie}

Voor de risico-analyse is het studiegebied opgedeeld inde volgende deelgebieden (Figuur 1.2):

1. De Binnenbijster

2. Den Dulver

3. Tolweg Noord en Kwekel

4. De Schans en De Dullaard

5. De Dellen, De Hoven en Kruisvaart

6. Labbegat I en II en Zuidewijn

7. Landzicht, Labbegat III en IV en Binnenpolder van Besoijen

De elf gewenste en deels reeds aanwezige habitattypen stellen eisen aan hun milieu die zijn samengevat (Tabel 3.1) en is de gewenste ligging van negen typen op kaart weergegeven (Figuur 3.4).

Tabel 3.1: Milieurandvoorwaarden habitattypen (Nieuwkamer et al. 2019).

\begin{tabular}{|c|c|c|c|}
\hline Habitattype & Vocht & Zuurgraad & Voedselrijkdom \\
\hline $\begin{array}{l}\text { H3130 } \\
\text { Zwakgebufferde } \\
\text { vennen }\end{array}$ & $\begin{array}{l}\text { diep water - 's } \\
\text { winters inunderend }\end{array}$ & $\begin{array}{l}\text { neutraal - matig } \\
\text { zuur }\end{array}$ & $\begin{array}{l}\text { zeer voedselarm- } \\
\text { matig voedselrijk }\end{array}$ \\
\hline $\begin{array}{l}\text { H3140 } \\
\text { Kranswierwateren } \\
\text { op hogere } \\
\text { zandgronden }\end{array}$ & $\begin{array}{l}\text { diep water - zeer } \\
\text { vochtig }\end{array}$ & $\begin{array}{l}\text { matig zuur - } \\
\text { neutraal/basisch }\end{array}$ & $\begin{array}{l}\text { voedselarm - matig } \\
\text { voedselrijk }\end{array}$ \\
\hline $\begin{array}{l}\text { H3150 } \\
\text { Kranswierwateren } \\
\text { op laagveen }\end{array}$ & diep water & basisch-neutraal & matig voedselrijk \\
\hline H4010A Vochtige & zeer nat - zeer & matig zuur - zuur & zeer voedselarm \\
\hline
\end{tabular}




\begin{tabular}{|c|c|c|c|}
\hline Habitattype & Vocht & Zuurgraad & Voedselrijkdom \\
\hline heide & vochtig & & \\
\hline $\begin{array}{l}\text { H6410 } \\
\text { Blauwgraslanden }\end{array}$ & nat - vochtig & matig zuur & voedselarm \\
\hline $\begin{array}{l}\text { H6430A Ruigten } \\
\text { met moerasspirea }\end{array}$ & $\begin{array}{l}\text { zeer nat - zeer } \\
\text { vochtig }\end{array}$ & $\begin{array}{l}\text { neutraal - matig } \\
\text { zuur }\end{array}$ & $\begin{array}{l}\text { matig voedselrijk - } \\
\text { zeer voedselrijk }\end{array}$ \\
\hline H7140A Trilvenen & $\begin{array}{l}\text { 's winters } \\
\text { inunderend - zeer } \\
\text { nat }\end{array}$ & $\begin{array}{l}\text { neutraal - matig } \\
\text { zuur }\end{array}$ & licht voedselrijk \\
\hline $\begin{array}{l}\text { H7140B } \\
\text { Veenmosrietland }\end{array}$ & zeer nat & matig zuur & licht voedselrijk \\
\hline $\begin{array}{l}\text { H7150 } \\
\text { Pioniervegetatie } \\
\text { met snavelbiezen }\end{array}$ & zeer nat - nat & zeer voedselarm & zeer voedselarm \\
\hline $\begin{array}{l}\text { H7230 } \\
\text { Kalkmoerassen }\end{array}$ & zeer nat - nat & neutraal/basisch & $\begin{array}{l}\text { voedselarm - matig } \\
\text { voedselrijk }\end{array}$ \\
\hline $\begin{array}{l}\text { H91E0C Vochtige } \\
\text { alluvile bossen }\end{array}$ & $\begin{array}{l}\text { zeer nat - zeer } \\
\text { vochtig }\end{array}$ & $\begin{array}{l}\text { matig zuur - } \\
\text { neutraal/basisch }\end{array}$ & matig voedselrijk \\
\hline
\end{tabular}

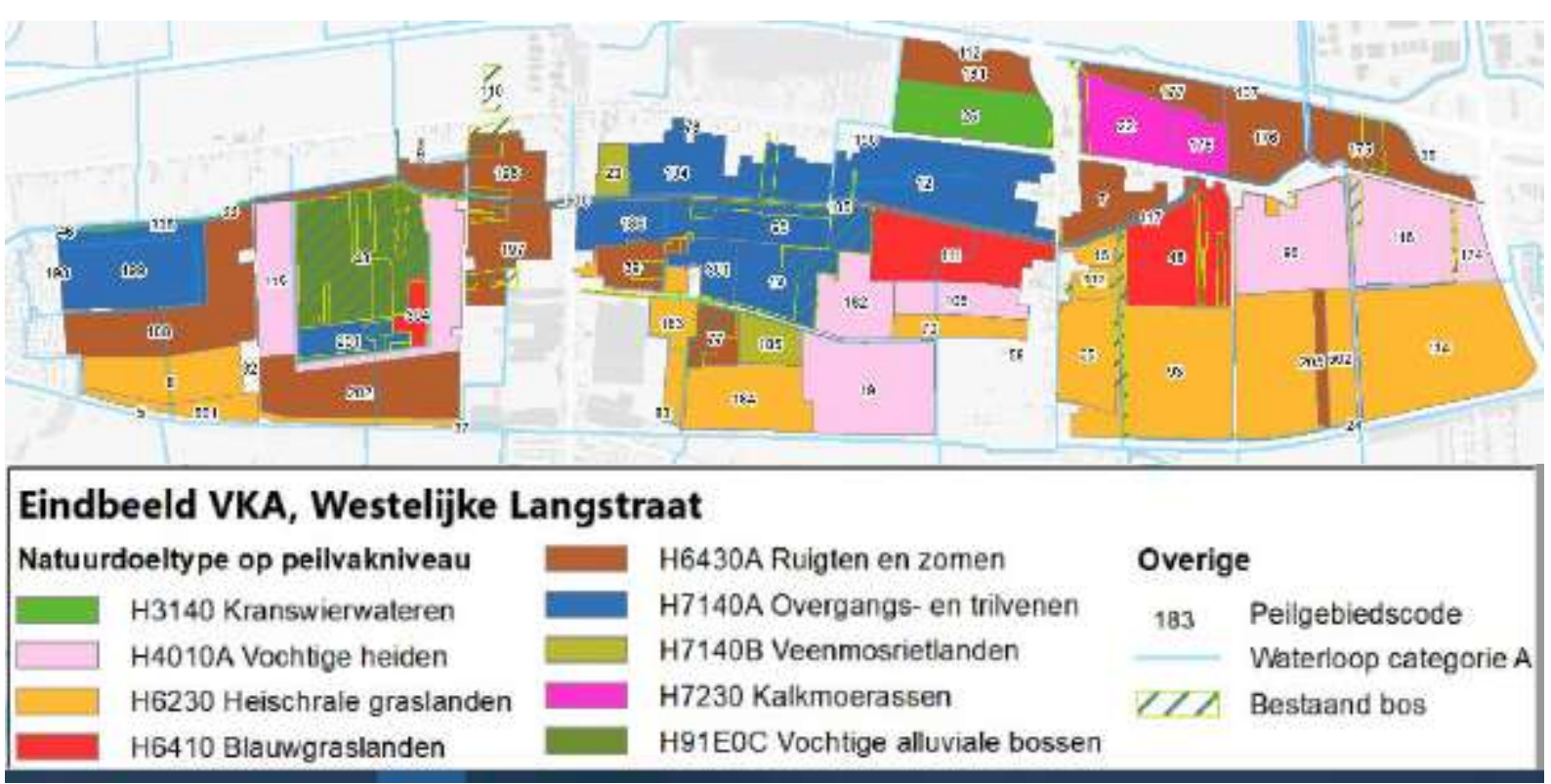

Figuur 3.4: Ligging van de tien gewenste habitattypen. Opmerking: De provincie heeft naar aanleiding van de zienswijzen, na de analyse gepresenteerd in dit rapport, de ambitietypenkaart aangepast.

Om aan de vooral hydrologische eisen te voldoen zijn maatregelen genoemd in het voorkeursalternatief:

Hydrologisch

- Aanbrengen van stuwen, duikers, gemaaltjes, dammen

- Graven en of aanpassen van nieuwe watergangen

- (Geleidelijk) aanpassen van peilen

Morfologisch/Chemisch

- Afgraven van voedselrijke bovengrond

Op hoofdlijnen kunnen deze maatregelen effecten hebben op de ontwikkelingskansen voor stekende insecten (Tabel 3.2).

Tabel 3.2: Invloed van de maatregelen op hydrologie en stekende insecten.

\begin{tabular}{|l|l|l|}
\hline Maatregelgroep & Effect(en) & $\begin{array}{l}\text { Effect op stekende } \\
\text { insecten }\end{array}$ \\
\hline Hydrologische maatregelen & $\begin{array}{l}\text { Stabiliseren (grond)waterpeil, } \\
\text { verhogen (grond)waterpeil, }\end{array}$ & $\begin{array}{l}\text { Tijdelijke wateren in het } \\
\text { voorjaar of zomer zijn }\end{array}$ \\
\hline
\end{tabular}




\begin{tabular}{|l|l|l|}
\hline & $\begin{array}{l}\text { verminderen afwatering. Door } \\
\text { peilverhoging in het gebied wordt } \\
\text { de overgang naar de randzone } \\
\text { dynamischer. Bij vernatten } \\
\text { bepaald de mate van tijdelijke } \\
\text { wateren de omstandigheden. }\end{array}$ & $\begin{array}{l}\text { potentiele broedgebieden, } \\
\text { permanente wateren juist } \\
\text { niet. Water aan maaiveld is } \\
\text { optimaal voor knuttenlarven. }\end{array}$ \\
\hline Morfologische maatregelen & $\begin{array}{l}\text { Maaiveld minder fosforrijk en } \\
\text { dichter bij grondwater. }\end{array}$ & $\begin{array}{l}\text { Tijdelijke wateren in het } \\
\text { voorjaar of zomer zijn } \\
\text { potentiele broedgebieden, } \\
\text { permanente wateren juist } \\
\text { niet. Water aan maaiveld is } \\
\text { optimaal voor knuttenlarven. }\end{array}$ \\
\hline
\end{tabular}

Dit leidt in het voorkeursalternatief tot verschillende milieu-omstandigheden die per deelgebied worden besproken.

\section{De Binnenbijster}

De bodem verloopt van noord naar zuid van meerveengronden op veen (smalle zone) naar meerveengronden op zand moerige podzol- naar veldpodzolgronden. Het betreft steeds een zanddek op veen en deze zandige gronden hebben matig tot geen organisch materiaal en hoge fosforgehaltes. De GHG neemt toe in de vorm van een halve cirkel van west $(0 \mathrm{~cm})$ naar oost (20 $\mathrm{cm}$ - maaiveld). Een groot deel van het deelgebied gaat sterkere kwel ( $>3 \mathrm{~mm})$ ontvangen. De verwachtte natuurdoeltypen verlopen van overgangs- en trilveen (noordwest), naar ruigtezoom naar heischraal grasland (zuid).

De grootste voorjaarsdynamiek in 'water wel/niet op maaiveld' treedt op in de ruigtezoom een zone die ook matig-zeer voedselrijk is (Figuur 3.5).

\section{Den Dulver}

De kern van het deelgebied is een moerige eergrond met een moerige bovengrond op zand met daar omheen vlierveen, en daar weer omheen meerveen op zand zonder humuspodzol en zuidelijker met humuspodzol met aan de zuidrand moerige pozolgronden met zanddek en moerige tussenlaag. De kern bevat meer organisch materiaal dat beter water vast kan houden en inzijging vertraagd. De gronden zijn met fosfor verrijkt. Delen worden $20-30 \mathrm{~cm}$ (zuid) afgegraven en worden daardoor armer in fosfor. De hoger gelegen kop Den Dulver komt daardoor nog hoger boven de omgeving. De GHG neemt met $10 \mathrm{~cm}$ (noord) tot 20 en plaatselijk $30 \mathrm{~cm}$ toe. Een groot deel van het deelgebied gaat weinig kwel $(<0.5 \mathrm{~mm})$ ontvangen of wordt inzijgend (kern Den Dulver).

De verwachtte natuurdoeltypen zijn een groot vochtig alluviaal bos met daaromheen vochtige heide (waar 10-20 cm is afgegraven), overgangs- en trilveen, een blauwgraslandje en ruigtezoom. Er ontstaat een grote hydrologisch dynamische plas-dras zone in Den Dulver, het alluviale bos met een matig-hoge fosforrijkdom (Figuur 3.6).

\section{Tolweg Noord en de Kwekel}

De bodem verloopt van noord naar zuid van meerveengronden op veen naar meerveengronden op zand. Het betreft zandige gronden met matig tot geen organisch materiaal en hoge fosforgehaltes. De GHG neemt met $20 \mathrm{~cm}$ toe. Het verwachtte natuurdoeltype is ruigtezoom. Er ontstaat een kleinere plas-dras zone in de Kwekel (Figuur 3.7). 

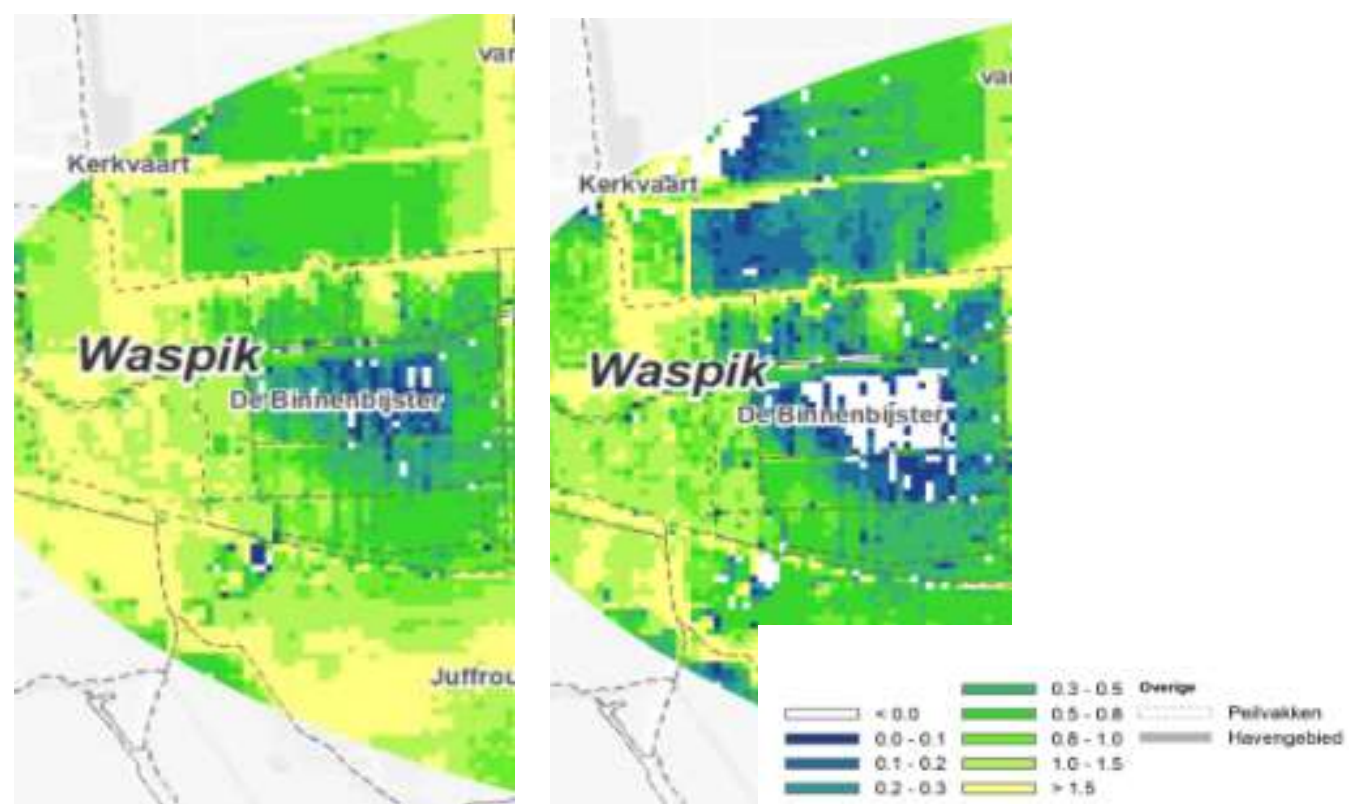

Figuur 3.5: De GLG (links) en GHG (rechts in en rondom de Binnenbijster. Schaal legenda in cm mv. Wit duidt op permanent water en van donkerblauw naar middelblauw verloopt de wegzakking tot $20 \mathrm{~cm}-\mathrm{mv}$.
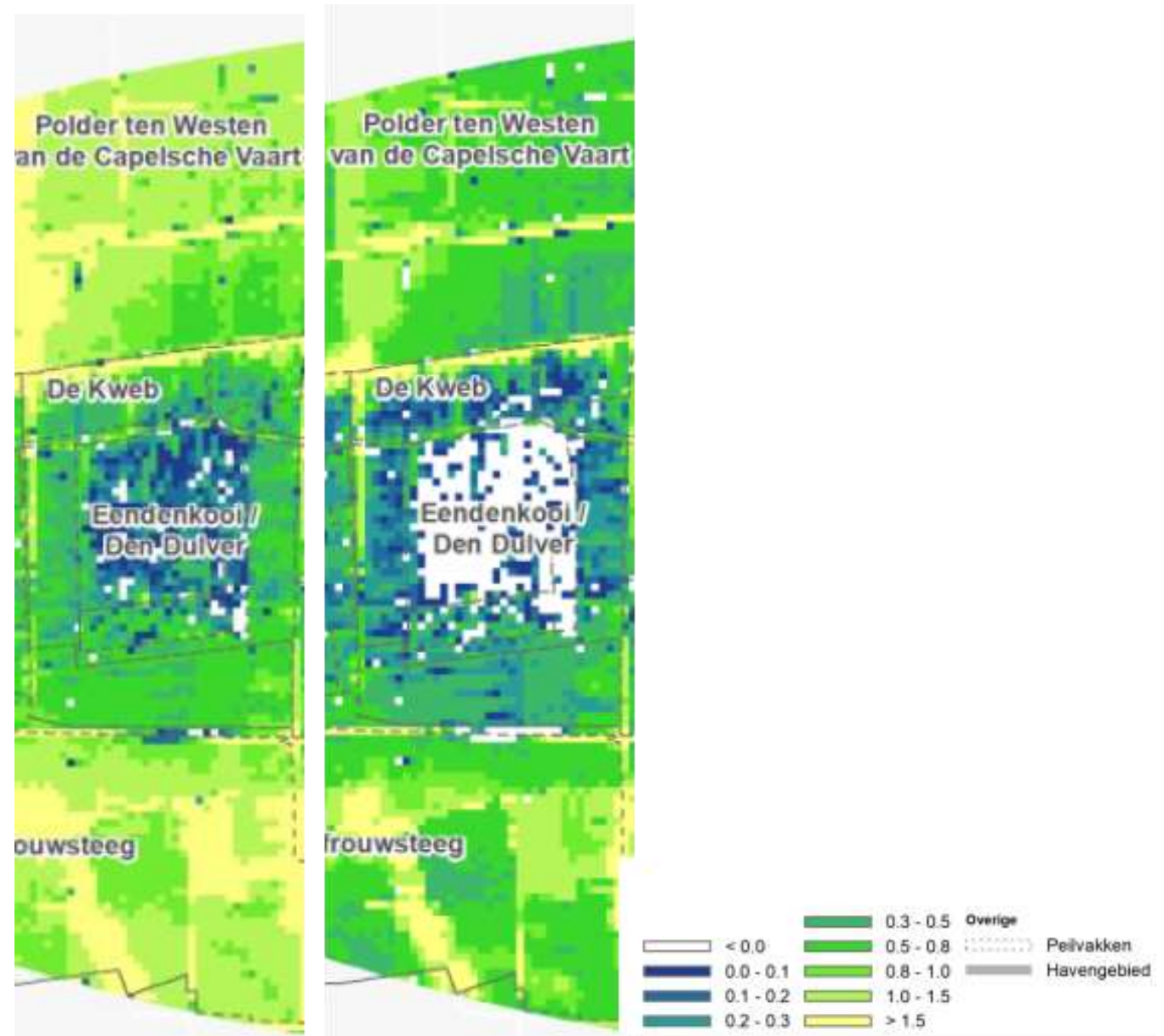

Figuur 3.6: De GLG (links) en GHG (rechts in en rondom de Den Dulfer. Schaal legenda in cm -mv. Wit duidt op permanent water en van donkerblauw naar middelblauw verloopt de wegzakking tot $20 \mathrm{~cm}-\mathrm{mv}$. 


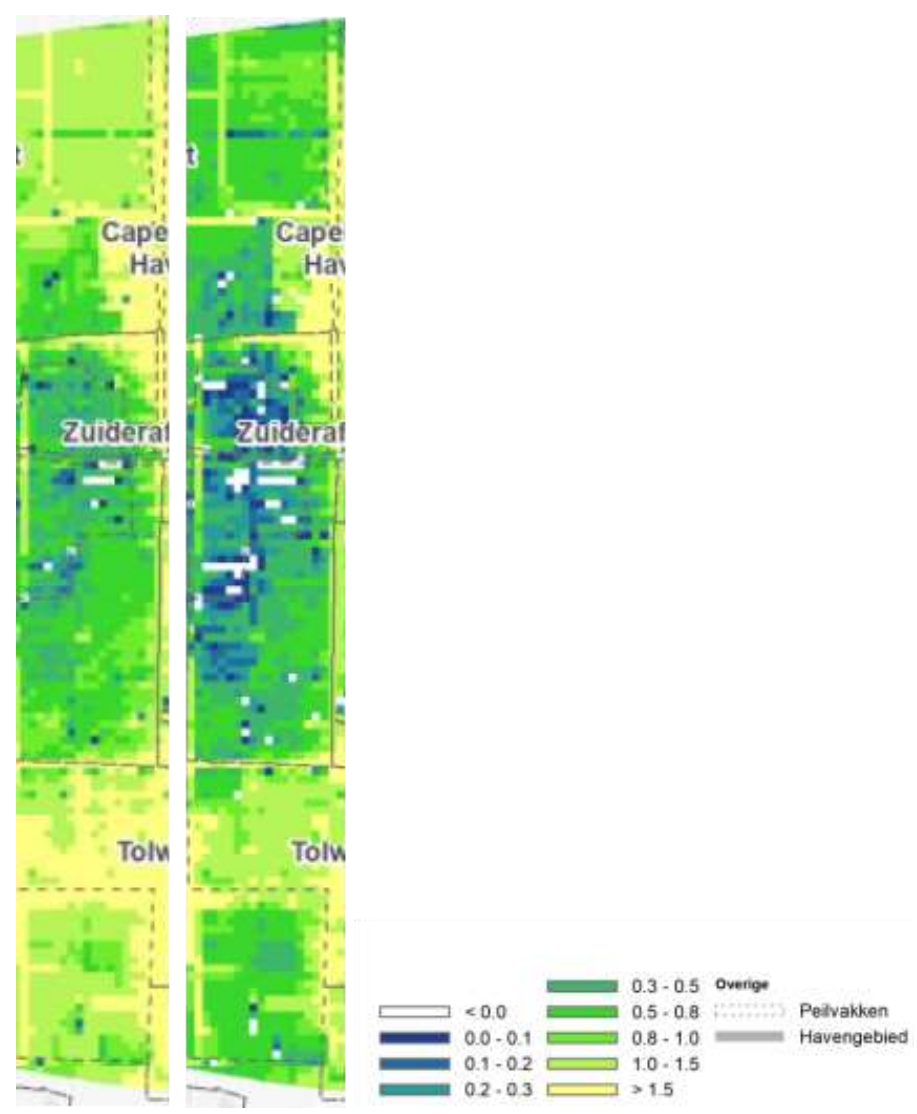

Figuur 3.7: De GLG (links) en GHG (rechts in en rondom Tolweg Noord en Kwekel. Schaal legenda in $\mathrm{cm}-m v$. Wit duidt op permanent water en van donkerblauw naar middelblauw verloopt de wegzakking tot $20 \mathrm{~cm}-\mathrm{mv}$.
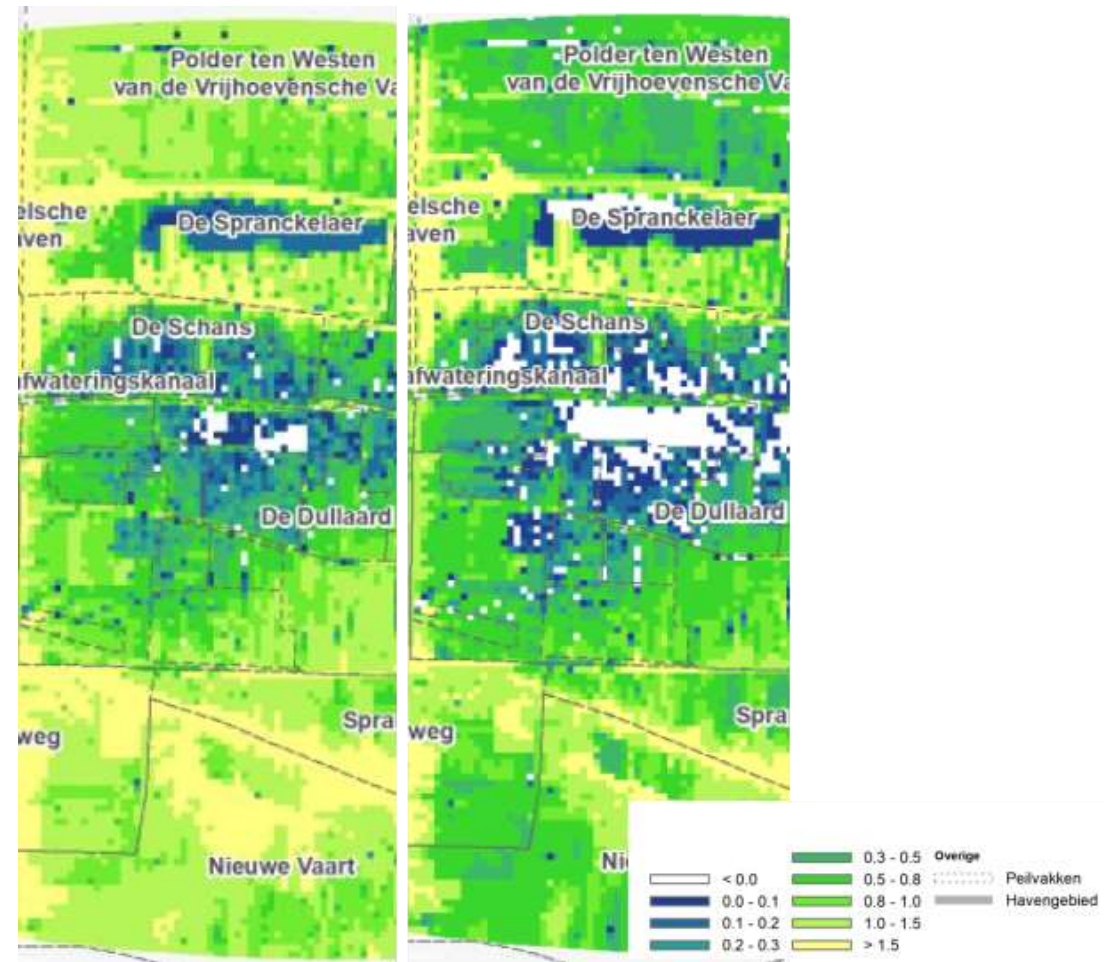

Figuur 3.8: De GLG (links) en GHG (rechts in en rondom De Schans en De Dullaard. Schaal legenda in $\mathrm{cm}-\mathrm{mv}$. Wit duidt op permanent water en van donkerblauw naar middelblauw verloopt de wegzakking tot $20 \mathrm{~cm}-m v$. 

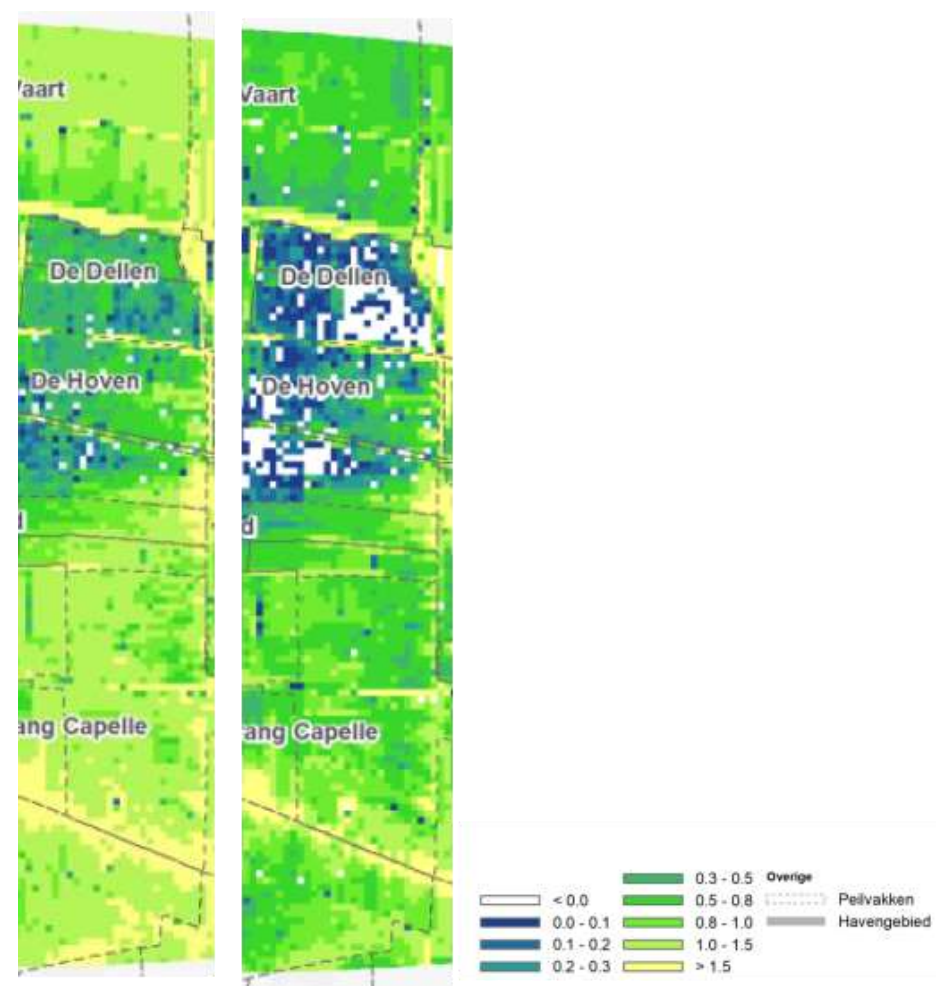

Figuur 3.9: De GLG (links) en GHG (rechts) in en rondom De Dellen, De Hoven en Kruisvaart. Schaal legenda in $\mathrm{cm}-m v$. Wit duidt op permanent water en van donkerblauw naar middelblauw verloopt de wegzakking tot $20 \mathrm{~cm}-\mathrm{mv}$.
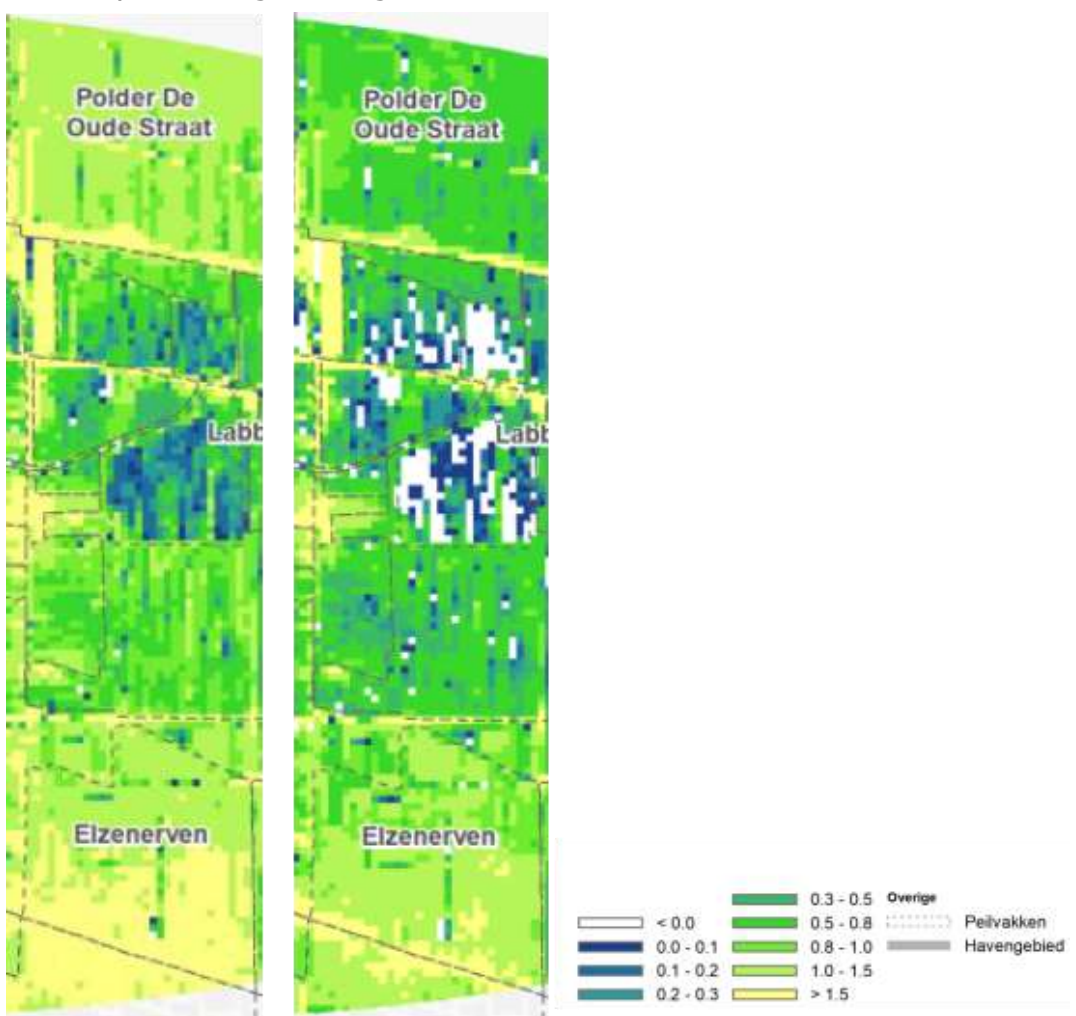

Figuur 3.10: De GLG (links) en GHG (rechts) in en rondom Labbegat I en II en Zuidewijn. Schaal legenda in $\mathrm{cm}-\mathrm{mv}$. Wit duidt op permanent water en van donkerblauw naar middelblauw verloopt de wegzakking tot $20 \mathrm{~cm}-\mathrm{mv}$. 


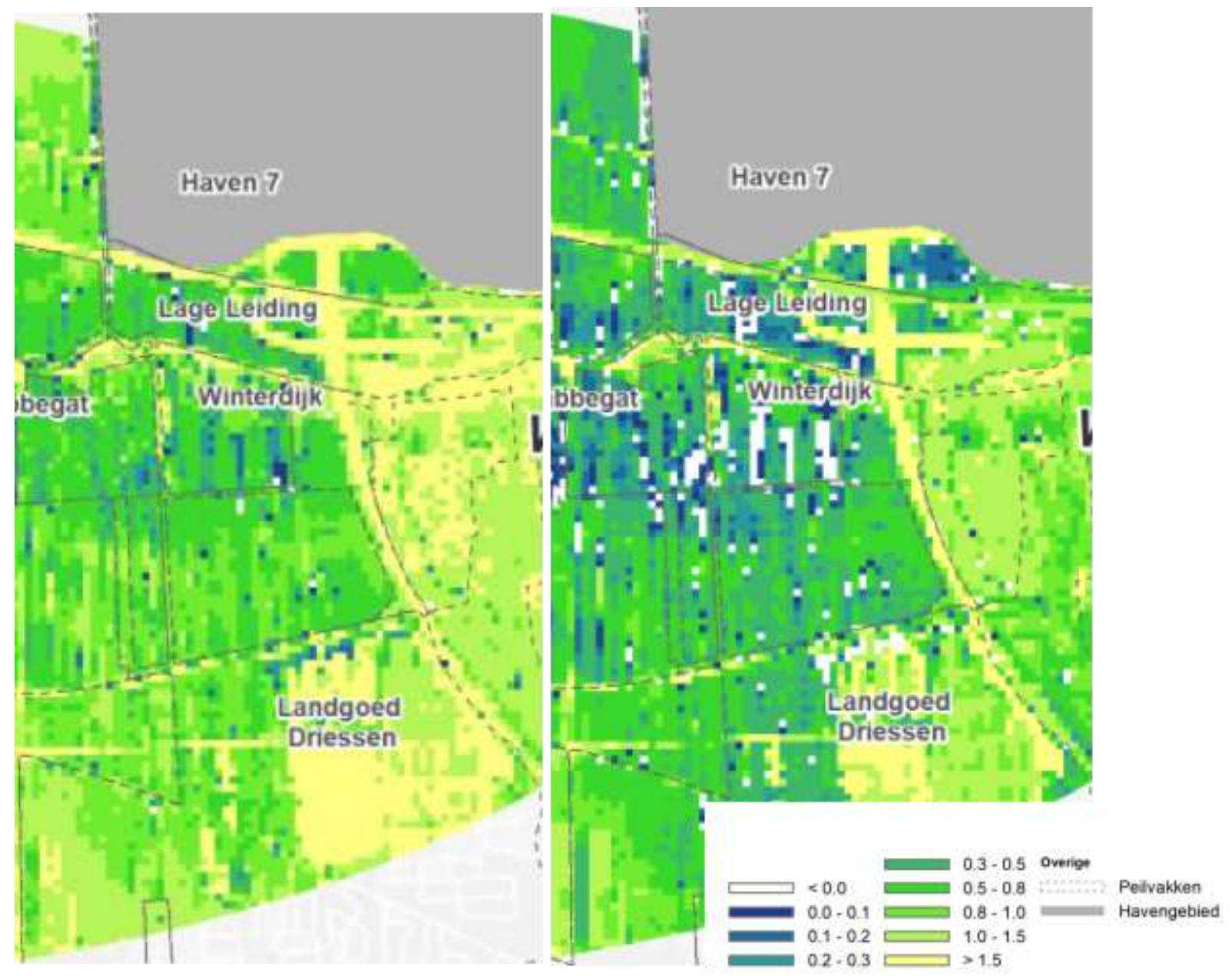

Figuur 3.11: De GLG (links) en GHG (rechts) in en rondom Landzicht, Labbegat III en IV en Binnenpolder van Besoijen. Schaal legenda in $\mathrm{cm}-m v$. Wit duidt op permanent water en van donkerblauw naar middelblauw verloopt de wegzakking tot $20 \mathrm{~cm}-\mathrm{mv}$.

\section{De Schans en De Dullaard}

De bodem verloopt van noord naar zuid van meerveengronden zonder humuspodzol (noord; De Schans) naar moerige podzol-, meerveen- en hoge zwarte enkeerd in het zuidoosten. Het betreft steeds een zanddek op veen. Het betreft zandige gronden met matig tot geen organisch materiaal en hoge fosfor gehaltes. De GHG neemt met $20-30 \mathrm{~cm}$ toe. Er is sterk mozaïek van sterke kwel ( $>3 \mathrm{~mm}$ ) tot infiltratie plekken. De verwachtte natuurdoeltypen verlopen van heischraal grasland via overgangs- en trilveenruigtezoom en opnieuw heischraal grasland (zuid) met lokaal een veenmosrietland.

De grootste voorjaarsdynamiek in 'water wel/niet op maaiveld' treedt op in De Dullaard op, in de ruigtezoom een zone die ook (zeer) voedselrijk is (Figuur 3.8).

\section{De Dellen, De Hoven en Kruisvaart}

De bodem verloopt van moerige podzol- en eerdgrond met klei- of zaveldek (noord De Dellen), via meerveengronden zonder humuspodzol, moerige podzol-, meerveen- en hoge zwarte enkeerd- en gooreerdgronden. Het betreft zandige gronden met matig tot geen organisch materiaal en hoge fosfor gehaltes. De GHG neemt met $20 \mathrm{~cm}$ (noord) toe tot $>50 \mathrm{~cm}$ (Den Dullaard) om weer af tem lopen naar $20 \mathrm{~cm}$ ten zuiden.

Van noord naar zuid liggen percelen met de natuurdoeltypen ruigtezoom, kranswierwater $(0-55 \mathrm{~cm}$ afgegraven), overgangs- en trilveen (10-40 cm afgegraven van maaiveld), blauwgrasland (10-40 $\mathrm{cm}$ afgegraven) en vochtige heide met nog een strook heischraal grasland. Er ontstaat een grote plas-dras zone in De Delllen en De Hoven een matig-hoge fosforrijkdom (Figuur 3.9). 


\section{Labbegat I en II en Zuidewijn}

De bodem verloopt van een smalle strook kalkrijke drechtvaaggrond (klei) via moerige podzolgrond met klei- of zaveldek in Labbegat I, naar een mozaïek van eerst meerveengronden met en zonder humuspodzol en veldpozolgronden naar hoge zwarte enkeerdgrond en lage enkeerdgronden. In kort verloopt de bodem van klei via veen naar zand, steeds met hoge fosforgehaltes. De GHG verloopt van een toename van $20 \mathrm{~cm}$ naar $30 \mathrm{~cm}$ en weer af naar $20 \mathrm{~cm}$. Van noord naar zuid liggen percelen met de natuurdoeltypen ruigtezoom, kalkmoeras (deels voor $45 \mathrm{~cm}$ afgegraven), ruigtezoom, blauwgrasland en een groot gebied heischraal grasland. In de noordelijke helft van Labbegat II ontstaat een plas-dras zone met een matig-hoge fosforrijkdom (Figuur 3.10).

\section{Landzicht, Labbegat III en IV en Binnenpolder van Besoijen}

De bodem bestaat hoofdzakelijk uit hoge zwarte enkeerdgronden met een kern van moerige podzolgronden met humushoudend zanddek en moerige tussenlaag en meerveengronden op zand met humuspodzolgronden, en aan de westrand veldpodzolgronden. Het betreft zandige gronden met matig tot geen organisch materiaal en hoge fosfor gehaltes. De GHG verloopt van een toename van $20 \mathrm{~cm}$ naar $30 \mathrm{~cm}$ en weer af naar $20 \mathrm{~cm}$. Van noord naar zuid liggen percelen met de natuurdoeltypen ruigtezoom (Landzicht), vochtige heide (Labbegat III en IV) en een groot gebied heischraal grasland (Binnenpolder van Besoijen). In Labbegat III en IV ontstaat een plasdras zone en oppervlak met water aan het maaiveld met een matig-hoge fosforrijkdom (Figuur 3.11).

Omdat de provincie naar aanleiding van de zienswijzen de ambitietypenkaart heeft aangepast zijn er ook, zei het kleine, wijzigingen ten opzichte van de VKA kaart. Zo zijn de ambities van heischrale graslanden en vochtige heide omgezet naar kruidenrijke en faunarijke graslanden, vochtige hooilanden en natte schraallanden. Met andere woorden de ambitie om voedselarmere vegetatietypen te bereiken zijn enigszins bijgesteld. Voor de conclusies rondom de stekende insecten veranderd hierdoor weinig omdat onder deze voedselrijkdom omstandigheden de respons van stekende insecten vooral samenhangt met de hydrologische condities.

\subsection{Ontwikkeling van larven van stekende insecten}

De ontwikkeling van stekende insecten hangt direct samen met de situaties waarin in voorjaar of zomer het water op (steekmuggen) of aan (knutten, dazen) maaiveld staat.

Er kunnen twee invalshoeken worden genomen; via de te verwachten natuurdoeltypen of per deelgebied.

\section{Ontwikkeling naar natuurdoeltype}

Voor de risico-analyse zijn de natuurdoeltypen die voor het gebied nagestreefd worden vertaald in landschapselementen gerelateerd aan stekende insecten (Tabel 3.3). Bij deze vertaling is per type ook de informatie over hydrologie, zuurgraad en voedselrijkdom meegenomen.

Tabel 3.3: Omschrijving van milieu-eisen van de natuurdoeltypen en de voor stekende insecten relevante landschapselementen.

\begin{tabular}{lll}
\hline Habitattype & Milieu & Landschapstype \\
\hline Zwakgebufferd ven & $\begin{array}{l}\text { diep, neutraal-matig zuur, (zeer } \\
\text { voedselarm)-matig voedselrijk }\end{array}$ & $\begin{array}{l}\text { Stilstaand open water (voedselarm-matig } \\
\text { voedselrijk) }\end{array}$ \\
\hline $\begin{array}{l}\text { Kranswierwater op } \\
\text { zand }\end{array}$ & $\begin{array}{l}\text { diep tot vochtig, (matig zuur)- } \\
\text { basisch, (voedselarm)-matig } \\
\text { voedselrijk }\end{array}$ & $\begin{array}{l}\text { Stilstaand open water (voedselarm-matig } \\
\text { voedselrijk) }\end{array}$ \\
\hline $\begin{array}{l}\text { Kranswierwater op } \\
\text { laagveen }\end{array}$ & $\begin{array}{l}\text { diep, neutraal-basisch, matig } \\
\text { voedselrijk }\end{array}$ & Stilstaand open water ((matig) voedselrijk) \\
\hline $\begin{array}{l}\text { Inundatiezone } \\
\text { zwakgebufferd ven }\end{array}$ & $\begin{array}{l}\text { tijdelijk, matig zuur-neutraal, (zeer } \\
\text { voedselarm)-matig voedselrijk }\end{array}$ & Oever-verlandingszone (arm) \\
$\begin{array}{l}\text { Oeverzone } \\
\text { kranswierwater (matig } \\
\text { rijk) }\end{array}$ & tijdelijk, neutraal, (matig) voedselrijk & Oever-verlandingszone (matig) \\
\hline
\end{tabular}




\begin{tabular}{|c|c|c|}
\hline Habitattype & Milieu & Landschapstype \\
\hline $\begin{array}{l}\text { Oeverzone } \\
\text { kranswierwater (rijk) }\end{array}$ & $\begin{array}{l}\text { tijdelijk, neutraal-basisch, (zeer) } \\
\text { voedselrijk }\end{array}$ & Oever-verlandingszone (rijk) \\
\hline Vochtig alluviaal bos & $\begin{array}{l}\text { zeer nat-zeer vochtig, matig zuur- } \\
\text { neutraal, (matig) voedselrijk }\end{array}$ & (Zeer) nat bos (matig-rijk) \\
\hline $\begin{array}{l}\text { Inunderend vochtig } \\
\text { alluviaal bos }\end{array}$ & tijdelijk, neutraal, (zeer) voedselrijk & Inunderend-(zeer) nat bos (matig-rijk) \\
\hline Trilveen & $\begin{array}{l}\text { 's winters inunderend-zeer nat, } \\
\text { matig zuur-neutraal, licht voedselrijk }\end{array}$ & (Zeer) natte veenvegetatie ((matig) arm) \\
\hline Veenmosrietland & zeer nat, matig zuur, licht voedselrijk & $\begin{array}{l}\text { (Zeer) natte veenrietvegetatie ((matig) } \\
\text { arm) }\end{array}$ \\
\hline Kalkmoeras & $\begin{array}{l}\text { zeer nat-nat, neutraal/basisch, } \\
\text { voedselarm-matig voedselrijk }\end{array}$ & (Zeer) natte moerasvegetatie ((matig) rijk) \\
\hline Vochtige heide & $\begin{array}{l}\text { zeer nat-zeer vochtig, zuur-matig } \\
\text { zuur, zeer voedselarm }\end{array}$ & Vochtige-natte heide \\
\hline Blauwgrasland & nat-vochtig, matig zuur, voedselarm & (Zeer) nat hooiland (matig arm-matig rijk) \\
\hline Ruigte & $\begin{array}{l}\text { zeer nat-zeer vochtig, matig zuur- } \\
\text { neutraal, matig-zeer voedselrijk }\end{array}$ & (Zeer) nat grasland/ruigte (rijk) \\
\hline Ruigte inunderend & $\begin{array}{l}\text { tijdelijk, neutraal-basisch, zeer } \\
\text { voedselrijk }\end{array}$ & $\begin{array}{l}\text { Inunderend-nat moerasvegetatie (matig } \\
\text { rijk) }\end{array}$ \\
\hline $\begin{array}{l}\text { Pioniervegetatie met } \\
\text { snavelbiezen }\end{array}$ & zeer nat-nat, zeer voedselarm & Inunderend-natte pioniervegetatie (arm) \\
\hline
\end{tabular}

De landschapselementen zijn vervolgens gekoppeld aan risico op voorkomen van stekende insecten door het toepassen van de kennisregels uit de Leidraad (Tabel 3.4). Hieruit blijkt dat de hoogste kans op overlast door stekende insecten (risicoklasse 4 en 5) ontstaan bij inundatie/hydrologische dynamiek. Ook voedselrijkdom speelt een rol maar is moeilijker te duiden bij de matig voedselrijke tot voedselarme situaties omdat deze mate van voedselrijkdom minder effect heeft op de stekende insecten populaties.

Tabel 3.4: Koppeling van risicogroepen van stekende insecten aan landschapselementen.

Risicoscore: $0=$ geen tot $+++++=$ overlast.

\begin{tabular}{|c|c|c|c|c|c|}
\hline Risicosoortgroepen & & & & & \\
\hline Landschapselementen ( $G H G \mathrm{~cm}-m v$ ) & $\begin{array}{c}\text { moeras- } \\
\text { steekmug }\end{array}$ & $\begin{array}{c}\text { huis- } \\
\text { steekmug }\end{array}$ & slootmug & $\begin{array}{l}\text { plantenboor- } \\
\text { steekmug }\end{array}$ & knut \\
\hline Stilstaand open water (arm) & $0(+) 2$ & $0(+) 2$ & 0 & 0 & 0 \\
\hline Stilstaand open water ((matig) arm) & $0(+) 2$ & $0(+) 2$ & 0 & 0 & 0 \\
\hline Stilstaand open water (rijk) & 0 & $+(+) 2$ & $+(++) 2$ & $+(++) 2$ & $0(+) 2$ \\
\hline Oever-verlandingszone (arm) & $++(++) 1$ & $++(++) 1$ & $0(++) 1$ & $0(++) 1$ & $0(++) 1$ \\
\hline Oever-verlandingszone (matig) & $++(++) 1$ & $++(++) 1$ & $++(++) 1$ & $++(++) 1$ & $++(++) 1$ \\
\hline Oever-verlandingszone (rijk) & $++++(+) 1$ & $++++(+) 1$ & $++++(+) 1$ & $++++(+) 1$ & $++++(+) 1$ \\
\hline (Zeer) nat bos (matig-rijk) & $++(++) 1$ & $+(+) 1$ & 0 & 0 & $+(+) 1$ \\
\hline Inunderend-(zeer) nat bos (matig-rijk) & $++++(+) 2$ & $++(++) 2$ & 0 & 0 & $+(+) 2$ \\
\hline (Zeer) natte veenvegetatie ((matig) arm) & $++(+++) 1$ & $(+++) 1$ & 0 & $0(+) 2,1$ & $++(++) 1$ \\
\hline $\begin{array}{l}\text { (Zeer) natte veenrietvegetatie ((matig) } \\
\text { arm) }\end{array}$ & $+++(++) 1$ & $(+++) 1$ & $0(+) 2,1$ & $0(+) 2,1$ & $+++(+) 1$ \\
\hline (Zeer) natte moerasvegetatie ((matig) rijk) & $+++(++) 2,1$ & $++(+++) 2,1$ & $(+++) 2,1$ & $+(+++) 2,1$ & $+++(++) 2,1$ \\
\hline Vochtige-natte heide & $(+++) 1$ & $(+++) 1$ & 0 & 0 & $+(++) 1$ \\
\hline (Zeer) nat hooiland (matig arm-matig rijk) & $(++) 1$ & $(++++) 1$ & 0 & 0 & $++(++) 1$ \\
\hline (Zeer) nat grasland/ruigte (rijk) & $(++++) 1$ & $++(+++) 1$ & 0 & 0 & $+++(++) 1$ \\
\hline $\begin{array}{l}\text { Inunderend-nat moerasvegetatie (matig } \\
\text { rijk) }\end{array}$ & $++++(+) 2,1$ & $+++(++) 2,1$ & $(++) 2$ & $++(++) 2$ & $++(++) 1$ \\
\hline Inunderend-natte pioniervegetatie (arm) & $++(++) 2,1$ & $+++(++) 2,1$ & $(+) 2$ & $+(+) 2$ & $+(+++) 1$ \\
\hline
\end{tabular}

1: bij inundatie door grond-, regen- of oppervlaktewater; vaak wisseling van peil droog-nat

2: bij voedselverrijking en met soms het ontstaan kroosdek of rijke/ruige ontwikkeling emergente vegetatie 
Bij het vertalen van de theoretische risico's naar de nagestreefde natuurdoeltypen en gecorrigeerd voor oppervlakte in het studiegebied blijkt samenvattend dat:

\begin{tabular}{ll}
\hline Landschapstype & Risico \\
\hline Stilstaand open water (arm) & Geen \\
Stilstaand open water ((matig) arm) & Geen \\
Stilstaand open water (rijk) & Laag \\
Oever-verlandingszone (arm) & Matig \\
Oever-verlandingszone (matig) & Matig \\
Oever-verlandingszone (rijk) & Groot \\
(Zeer) nat bos (matig-rijk) & Matig \\
Inunderend-(zeer) nat bos (matig-rijk) & Groot \\
(Zeer) natte veenvegetatie ((matig) arm) & Matig-Groot \\
(Zeer) natte veenrietvegetatie ((matig) arm) & Matig-Groot \\
(Zeer) natte moerasvegetatie ((matig) rijk) & Matig-Groot \\
Vochtige-natte heide & Laag \\
(Zeer) nat hooiland (matig arm-matig rijk) & Laag \\
(Zeer) nat grasland/ruigte (rijk) & Matig \\
Inunderend-nat moerasvegetatie (matig rijk) & Groot \\
Inunderend-natte pioniervegetatie (arm) & Groot \\
\hline
\end{tabular}

\section{Ontwikkeling naar deelgebied}

Voor de benadering met de maatregeleffecten per deelgebieden zijn de deelgebieden gekoppeld aan de bodem, de hydrologie, de ingrepen en de natuurdoeltypen in paragraaf 3.2. Maatregelen hebben ieder een eigen effect op stekende insecten (Tabel 3.2).

Tabel 3.5: Koppeling van maatregelen in deelgebieden aan de milieu-omstandigheden en de effecten op stekende insecten.

\begin{tabular}{|c|c|c|}
\hline $\begin{array}{l}\text { Deelgebied } \\
\text { (Figuur } 3.6 \text { ) }\end{array}$ & Milieu-omstandigheden & Effect op stekende insecten \\
\hline De Binnenbijster & $\begin{array}{l}\text { Het deelgebied is zandig en } \\
\text { ontvangt kwel. Er treedt een } \\
\text { grote voorjaarsdynamiek in 'water } \\
\text { wel/niet op maaiveld' op (zie } \\
\text { Figuur 3.5) in een zone die ook } \\
\text { matig-zeer voedselrijk is. }\end{array}$ & $\begin{array}{l}\text { Een-derde van het deelgebied heeft } \\
\text { tijdelijk water in een matig voedselrijke } \\
\text { tot voedselrijke situatie wat een } \\
\text { broedplaats kan leveren voor } \\
\text { moerassteekmuggen mits het water tot } \\
\text { begin mei ongeveer aanwezig is. Het is } \\
\text { waarschijnlijk dat dit bij deze kweldruk } \\
\text { optreedt. In de zones daaromheen } \\
\text { waar het water ook's zomers vlak } \\
\text { onder maaiveld blijft is kans op } \\
\text { knutten. Bij lagere grondwaterstanden } \\
\text { zijn weiniq effecten te verwachten. }\end{array}$ \\
\hline Den Dulver & $\begin{array}{l}\text { Het deelgebied is venig, bevat } \\
\text { meer organisch materiaal wat } \\
\text { water beter vasthoudt en inzijging } \\
\text { vertraagd. Er ontstaat een grote } \\
\text { hydrologisch dynamische plas- } \\
\text { dras situatie met een zwakke } \\
\text { kweldruk of infiltratie in een } \\
\text { voedselrijker milieu met bos } \\
\text { begroeid. }\end{array}$ & $\begin{array}{l}\text { De helft van het deelgebied bevat } \\
\text { tijdelijk water met hogere } \\
\text { voedselrijkdom wat in het bos zeker } \\
\text { een broedplaats kan leveren voor } \\
\text { moerassteekmuggen mits het water tot } \\
\text { begin mei ongeveer aanwezig is. In de } \\
\text { zones daaromheen waar het water ook } \\
\text { 's zomers vlak on der maaiveld blijft is } \\
\text { kans op knutten. Bij lagere } \\
\text { grondwaterstanden zijn weinig effecten } \\
\text { te verwachten. } \\
\text { De verminderde wegzijging kan tijdens } \\
\text { natte zomers tot tijdelijk water leiden } \\
\text { hetgeen huissteekmuggen bevordert. }\end{array}$ \\
\hline
\end{tabular}




\begin{tabular}{|c|c|c|}
\hline $\begin{array}{l}\text { Deelgebied } \\
\text { (Figuur 3.6) }\end{array}$ & Milieu-omstandigheden & Effect op stekende insecten \\
\hline $\begin{array}{l}\text { Tolweg Noord en } \\
\text { Kwekel }\end{array}$ & $\begin{array}{l}\text { Het betreft zandige gronden met } \\
\text { matig tot geen organisch } \\
\text { materiaal en hoge fosforgehaltes. }\end{array}$ & $\begin{array}{l}\text { Er is nauwelijks sprake van tijdelijk } \\
\text { water op maaiveld wat het } \\
\text { onwaarschijnlijk maakt dat } \\
\text { moerassteekmuggen gaan optreden. In } \\
\text { de zomer zakt het grondwater ook } \\
\text { voldoende weg dat nauwelijks knutten } \\
\text { te verwachten zijn. }\end{array}$ \\
\hline $\begin{array}{l}\text { De Schans en De } \\
\text { Dullaard }\end{array}$ & $\begin{array}{l}\text { Het deelgebied is zandig met } \\
\text { matig tot geen organisch } \\
\text { materiaal, hoge fosfor gehaltes en } \\
\text { een groot mozaïek van sterke } \\
\text { kwel tot infiltratie. Er treedt een } \\
\text { voorjaarsdynamiek in 'water } \\
\text { wel/niet op maaiveld' op (zie } \\
\text { Figuur 3.8) in een zone die ook } \\
\text { (zeer) voedselrijk is. }\end{array}$ & $\begin{array}{l}\text { Een kwart van het deelgebied heeft } \\
\text { tijdelijk water in een matig voedselrijke } \\
\text { tot voedselrijke situatie wat een } \\
\text { broedplaats kan leveren voor } \\
\text { moerassteekmuggen mits het water tot } \\
\text { begin mei ongeveer aanwezig is. Het is } \\
\text { waarschijnlijk dat op plaatsen met } \\
\text { kweldruk en de zones daaromheen } \\
\text { waar het water ook's zomers vlak } \\
\text { onder maaiveld blijft knutten gaan } \\
\text { optreden. Bij lagere grondwaterstanden } \\
\text { zijn weinig effecten te verwachten. }\end{array}$ \\
\hline $\begin{array}{l}\text { De Dellen, De } \\
\text { Hoven en } \\
\text { Kruisvaart }\end{array}$ & $\begin{array}{l}\text { Het deelgebied is zandig met } \\
\text { matig tot geen organisch } \\
\text { materiaal en hoge fosfor gehaltes. } \\
\text { Er treedt een voorjaarsdynamiek } \\
\text { in 'water wel/niet op maaiveld' op } \\
\text { in een zone die ook (zeer) } \\
\text { voedselrijk is }\end{array}$ & $\begin{array}{l}\text { In De Dellen treedt tijdelijk water in } \\
\text { een matig voedselrijke tot voedselrijke } \\
\text { situatie op wat een broedplaats kan } \\
\text { leveren voor moerassteekmuggen mits } \\
\text { het water tot begin mei ongeveer } \\
\text { aanwezig is. In de zones daaromheen } \\
\text { waar het water ook's zomers vlak } \\
\text { onder maaiveld blijft is kans op knutten } \\
\text { maar het oppervlak is beperkt. Bij } \\
\text { lagere grondwaterstanden zijn weinig } \\
\text { effecten te verwachten. }\end{array}$ \\
\hline $\begin{array}{l}\text { Labbegat I en II en } \\
\text { Zuidewijn }\end{array}$ & $\begin{array}{l}\text { Het deelgebied heeft veen, klein } \\
\text { en zand. In een klein deel } \\
\text { ontstaat een plas-dras zone met } \\
\text { een matig-hoge fosforrijkdom. }\end{array}$ & $\begin{array}{l}\text { Alleen lokaal bestaat de kans op } \\
\text { moerassteekmuggen omdat daar } \\
\text { tijdelijk water in een matig voedselrijke } \\
\text { tot voedselrijke situatie bestaat, mits } \\
\text { het water tot begin mei ongeveer } \\
\text { aanwezig is. In de zones daaromheen } \\
\text { waar het water ook's zomers vlak } \\
\text { onder maaiveld blijft is kans op knutten } \\
\text { maar het oppervlak is beperkt. Bij } \\
\text { lagere grondwaterstanden zijn weinig } \\
\text { effecten te verwachten. }\end{array}$ \\
\hline $\begin{array}{l}\text { Landzicht, } \\
\text { Labbegat III en IV } \\
\text { en Binnenpolder } \\
\text { van Besoijen }\end{array}$ & $\begin{array}{l}\text { Het deelgebied bevat zand met } \\
\text { matig tot geen organisch } \\
\text { materiaal. In een klein deel } \\
\text { ontstaat een plas-dras zone met } \\
\text { een matig-hoge fosforrijkdom }\end{array}$ & $\begin{array}{l}\text { Plaatselijk treedt tijdelijk water op in } \\
\text { een matig voedselrijke tot voedselrijke } \\
\text { situatie wat een broedplaats kan } \\
\text { leveren voor moerassteekmuggen mits } \\
\text { het water tot begin mei ongeveer } \\
\text { aanwezig is. In kleine zones } \\
\text { daaromheen waar het water ook 's } \\
\text { zomers vlak onder maaiveld blijft is } \\
\text { kans op knutten. Bij lagere } \\
\text { grondwaterstanden zijn weinig effecten } \\
\text { te verwachten. }\end{array}$ \\
\hline
\end{tabular}

Samenvattend zijn beide invalshoeken te combineren tot een risicobeoordeling (Figuur 3.12). De variatie in risico op stekende insecten hangt samen met de mate waarin de hydrologische dynamiek beperkt kan worden (dat wil zeggen de kans op water op maaiveld klein is) en waarin de voedselrijkdom voldoende laag is. 


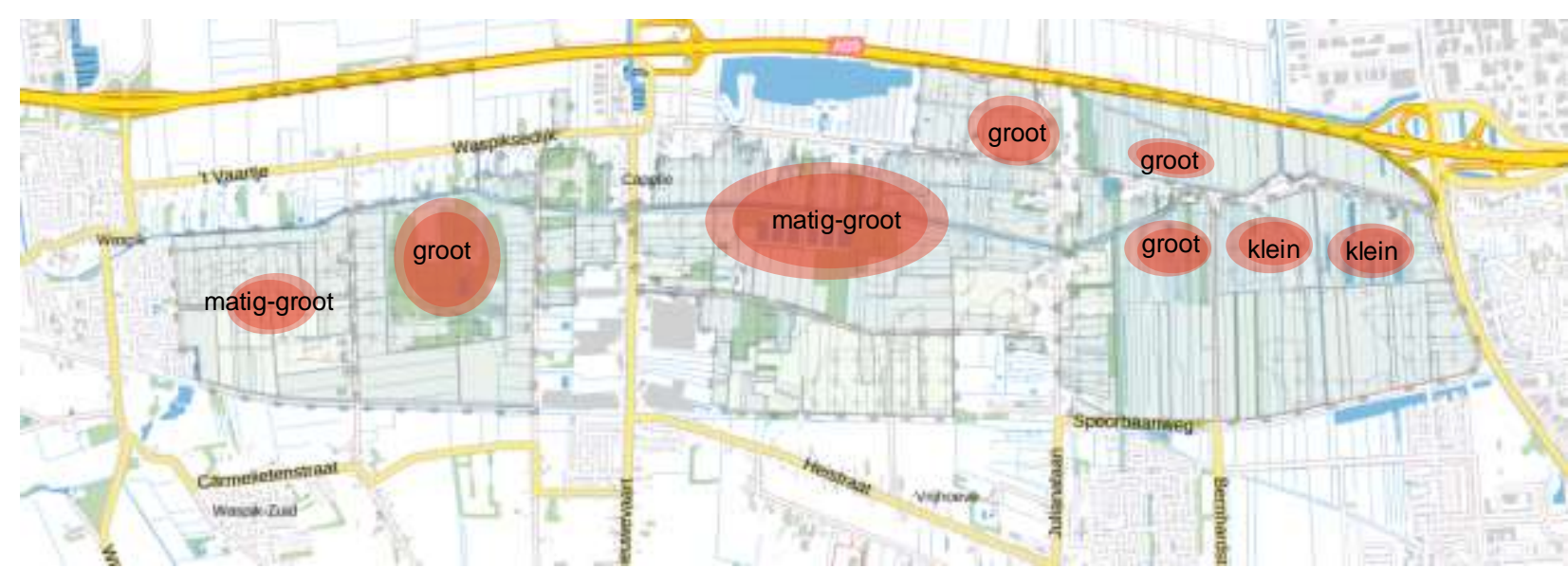

Figuur 3.12: Grove risicoschatting op stekende insecten (klasse in woorden: klein-matig-groot) in de locaties waar water op het land kan komen (rode binnen cirkel) en waar water aan maaiveld zou kunnen blijven (roze cirkel).

\subsection{Verspreiding van volwassen stekende insecten}

Nadat stekende insecten zijn uitgevlogen gaan ze op zoek naar bloed om hun eitjes te laten ontwikkelen. Ze kunnen daarvoor korte en lange afstanden afleggen. Steekmuggen zijn in 4 groepen vliegers te verdelen: sterke, goede, matige en zwakke vliegers (Verdonschot \& BesseLototskaya 2014). Ook voor knutten geldt dat het vliegvermogen sterk kan verschillen tussen soorten.

De afstand die wordt afgelegd hangt van allerlei factoren af, zoals de vliegcapaciteit van de soort, de aanwezigheid van prooien, de vegetatie structuur die als corridor of als barrière kan functioneren. Een barrière is gedefinieerd als een gebiedsdeel tussen broedgebied van de larven en de plaats waar overlast wordt verwacht (vaak bewoning) wat minder geschikt is voor volwassen dieren om te doorkruisen of verblijven. Broedgebieden zijn de plaatsen waar steekmuggen/knutten hun eitjes afzetten (op natte grond of op water) en waar de larven zich ontwikkelen (in de waterkolom) om via popstadium (in de waterkolom levend) te komen tot volwassen steekmuggen/knutten (die uit het water uitvliegen).

Een ruime afstand tussen mogelijke broedgebieden van steekmuggen en knutten en woningen (de plaats waar de volwassen steekmuggen naar toe vliegen) kan effectief werken tegen bepaalde soorten steekmuggen en knutten. Wanneer het tussenliggend gebied ook nog eens steekmug en knut onvriendelijk ingericht is gaat het tussenliggende gebied als barrière werken. Overlast veroorzaakt door zwakke en matige vliegers kan met barrières die op een juiste manier zijn ingericht worden beperkt. Voor de goede en sterke vliegers heeft een barrière veel minder effect. Van sommige knutten is bekend dat het zeer goede vliegers zijn en hiertegen hebben barrières eveneens minder effect.

Corridors zijn zones die juist verbindend werken. Corridors bestaan vaak uit houtige opslag zoals bosschages waar stekende insecten in kunnen schuilen en die ze gemakkelijk kunnen passeren. De ecologische groepen huis-, sloot- en moerassteekmuggen zijn niet één-op-één in vlieggroepen in te delen. Met andere woorden binnen iedere ecologische groep van steekmuggen zitten zowel zwakke als sterke vliegers. Van de plantenboorsteekmug, de Nederlandse soort, is ook geen vliegafstand bekend. Van de Nederlandse soorten knutten is weinig over vliegvermogen bekend.

De inrichting van een barrière is gericht op het bereiken van een lage luchtvochtigheid (te bereiken met zeer korte vegetatie of open water), vrijheid voor windwerking (wind beperkt de vliegmogelijkheden sterk) en ontbreken van corridors in de vorm van linten van bosschages of ruigten. Een extra versterking van een barrière is het aanleggen van bosschages aan de binnenzijde van het broedgebied om volwassen steekmuggen en knutten juist het gebied in te trekken i.p.v. het gebied uit, richting woningen, te laten vliegen. Deze zogenoemde muggenbosjes versterken de barrièrewerking. 
Open water functioneert ook als een goede barrière.

In deze studie is de afstand tussen bewoning en broedgebied (risicopercelen) en de begroeiing van deze zone onderzocht. Tenslotte gaat het om het risico voor omwonenden.

In het studiegebied is de begroeiing in de zone tussen larvaal broedgebied en de bewoning in het een belangrijk aandachtspunt omdat de bewoning pal op het gebied staat. Het gebied is ingeklemd door de woonkernen van Waspik, Capelle, Waalwijk Vrijhoeve, Nieuwe Vaart naast een recreatiepark aan de noordzijde.

De aantallen stekende insecten die zich in het gebied ontwikkelen hebben geen moeite om de circa 1-2 kilometer tussen broedgebied en bebouwing te overbruggen. Bossen, bosschages en ruigtezones bevorderen de verspreiding ook.

Een uiteindelijk risico op overlast voor omwonenden, waarvan de dichtstbijzijnde woning op zeer korte afstand verwijderd staat van een potentieel broedgebied en hangt direct samen met:

i. de draagkracht voor stekende insecten van de broedplaats (m.a.w. hoeveel stekende insecten komen uit het larvale studiegebied),

ii. welke begroeiing aanwezig is in het broedgebied (de aanwezige landschapselementen van het broedgebied),

iii. de vliegcapaciteit van de soort die zich ontwikkelt (hierbij moet worden bedacht dat maximale vliegcapaciteit ongelijk is aan 'normale' vliegafstand en ongelijk is aan overlast),

iv. de begroeiing (de landschapselementen en de daarin aanwezige prooien) die aanwezig is tussen het broedgebied en de bewoning omdat corridors de vliegroutes van de volwassen dieren bepalen en bij aanwezigheid van barrières deze dieren juist beperken.

De mogelijk te verwachten moerassteekmuggen, huissteekmuggen en knutten hebben een verschillende vliegcapaciteit van $<100 \mathrm{~m}$ tot $>2 \mathrm{~km}$. De soorten die in dit gebied te verwachten zijn kunnen allen meer dan 1-2 km vliegen. Uit het onderzoek blijkt dat met een barrière van $50-70 \mathrm{~m}$ een $90 \%$ vermindering in aantallen bereikt wordt van zwakke vliegers. Matige vliegers kunnen met een dergelijke barrière van 140-200 m met 90\% gereduceerd worden. Voor de goede en sterke vliegers zijn veel bredere barrières nodig om een $90 \%$ vermindering te bereiken. Daarbij bepalen de aantallen stekende insecten of een $90 \%$ reductie nodig is om toch geen overlast te krijgen.

Voor dit gebied is het dus niet mogelijk om met barrières het aantal te beperken, behalve binnen het gebied zelf.

Samenvattend kan worden geconcludeerd dat alleen met interne maatregelen, zoals het concentreren van volwassen dieren in bosschages en het bemoeilijken van verspreiding door open corridors van zeer korte vegetatie of open water, de kans op overlast van stekende insecten verkleind kan worden.

\subsection{Initiële fase na aanleg}

Tenslotte zal kort na de aanleg de kans op hoge aantallen zich ontwikkelende stekende insecten groter zijn dan jaren later wanneer het ecosysteem hersteld is en een nieuw evenwicht is ingesteld omdat voedselrijkdom is afgenomen en dynamiek is verminderd (geen vorming van langdurig stilstaand tijdelijk water op het land). Dan kunnen predatoren (zoals rovende insecten (b.v. roofkevers, libellelarven, vissen)) op de larven en insectenetende vogels en amfibieën op de volwassen dieren de aantallen enigszins reguleren. 


\section{Aanvullende maatregelen}

\subsection{Mogelijke aandachtspunten en aanvullende maatregelen}

In het algemeen zijn bij vernatting in het studiegebied een aantal maatregelen generiek van toepassing:

- $\quad$ Voorkom al te sterke wisselingen in oppervlaktewaterpeil en laat (langdurig) tijdelijk water in voorjaar oppervlakkig afstromen (greppelstructuur) m.a.w. zorg dat door fijnschalige inrichting en beheer de hydrologische dynamiek klein is.

- $\quad$ Laat bij (zeer) natte gronden het peil in voorjaar iets wegzakken zodat knutten minder kansen krijgen. Dit kan indien ook het vorige punt wordt bereikt.

- Beheer in de richting van (matig) voedselarmere situaties omdat dan minder voedsel beschikbaar is.

- $\quad$ Laat geen of zeer beperkt beweiding toe omdat beweiding tot bodemverdichting leidt en pootafdrukken tot kommetjes waar tijdelijke wateren in kunnen optreden.

- $\quad$ Richt waar mogelijk concentratiegebieden (bosschages los van bewoning in het gebeid zelf) voor stekende insecten in. Echter de schaal van het studiegebied maakt de uitvoering van deze maatregel moeilijk omdat concreet de bewoning overal te dicht bij de broedgebieden ligt.

Omdat het studiegebied veel mogelijkheden biedt om peilen te sturen is het onnodig meer in detail per deelgebied de maatregelen uit te splitsen. Waarschijnlijk wordt het peilbeheer en de waterbalans het belangrijkste sturingsinstrument.

\subsection{Beheer}

Het is nog onduidelijk hoe de vele en in een kleinschalig mozaïek verspreidde natuurdoeltypen beheerd gaan worden. Beheermaatregelen kunnen wel invloed hebben (positief en negatief) op het aantal stekende insecten (Tabel 4.1).

Tabel 4.1: Invloed van de maatregelen op hydrologie en stekende insecten.

\begin{tabular}{|c|c|c|}
\hline \multicolumn{3}{|c|}{ Beheermaatregelen } \\
\hline Maaien & Verminder structuur. & $\begin{array}{l}\text { Volwassen dieren hebben } \\
\text { minder corridor en } \\
\text { schuilplaats. }\end{array}$ \\
\hline Plaggen & $\begin{array}{l}\text { Maagdelijke grond gevoelig voor } \\
\text { tijdelijke oppervlaktewateren of } \\
\text { water tot maaiveld. }\end{array}$ & $\begin{array}{l}\text { Afwezigheid predatoren maakt } \\
\text { tijdelijk water potentieel } \\
\text { broedgebied. Tijdelijk water } \\
\text { aan maaiveld in verstoorde } \\
\text { grond is optimaal voor dazen. }\end{array}$ \\
\hline Begrazen & $\begin{array}{l}\text { Tijdelijke wateren op maaiveld in } \\
\text { pootafdrukken. Toevoer mest op } \\
\text { land. }\end{array}$ & $\begin{array}{l}\text { Tijdelijke wateren in } \\
\text { pootafdrukken in de zomer } \\
\text { zijn potentiele broedgebieden, } \\
\text { permanente wateren juist } \\
\text { niet. Water aan maaiveld is } \\
\text { optimaal voor knuttenlarven } \\
\text { vooral onder mest. }\end{array}$ \\
\hline
\end{tabular}




\section{Discussie, conclusies en aanbevelingen}

\subsection{Discussie en conclusies}

Deze studie had als doel het uitvoeren van een risico-analyse op de kans op het voorkomen van stekende insecten in de toekomstige situatie in en rondom de Westelijke Langstraat. Daarnaast was het opstellen van een advies voor het vóórkomen van overlast van stekende insecten door aanvullende maatregelen op basis van de voorgenomen herinrichting en beheer een tweede doel.

De te ontwikkelen natuur in de Westelijke Langstraat is vooral afhankelijk van hogere grondwaterstanden. In het voorkeursalternatief zijn maatregelen opgenomen om het gebied te vernatten en zo natte en moerassige omstandigheden te creëren. De beoogde natuurdoeltypen zijn vaak afhankelijk van voedselarme omstandigheden maar de uitgangssituatie is voedselrijk tot zeer voedselrijk. Dit betekent dat de hydrologische doelen (de natheid) sneller te behalen zijn dan de chemische (het verminderen van de voedselrijkdom). Maar ook hydrologisch is de mate van reductie in dynamiek (schommelingen in de (grond)waterstand nog niet helemaal duidelijk. De voorspellingen zijn gebaseerd op modelberekeningen waarvan de auteurs zelf al aangeven dat er onnauwkeurigheden zijn. Wel worden peilen geleidelijk ingesteld. Door het gebruik van peilvakken en een geleidelijke instelling kunnen initiële dynamische omstandigheden die zeer gunstig zijn voor stekende insecten, worden beheerd.

De bodemopbouw, hydrologische situatie (grondwaterstand, kwel druk, peil en dynamiek), ingrepen (afgraven) en beoogde natuurdoeltypen zijn gecombineerd tot een beeld van de toestand van landschapselementen, die al dan niet geschikt zijn voor de ontwikkeling van larven van stekende insecten. De milieu-omstandigheden van de gewenste natuurdoeltypen komen niet eenop-een overeen met die van de te verwachten omstandigheden., De reden is dat bij inundatie door grondwater (kwel tot boven maaiveld), regenwater (stagnatie van infiltratie van regenwater) of oppervlaktewater (peil in watergangen hoger dan maaiveld) de peilen vaker zullen wisselen dan modelberekeningen laten zien (er zit een grote onnauwkeurigheid op lokale schaal in de modeluitkomsten). Ook bij gedetailleerd beheer van de peilen blijft het de vraag of de gewenste milieu-omstandigheden daadwerkelijk haalbaar zijn (peilbeheer betekent niet dat hele percelen ook de gewenste (grond)waterstanden bereiken).

Daarnaast speelt voedselverrijking een belangrijke rol die vaak een gevolg is van het niet beschikbaar zijn van voedselarm water en vaak ook te veel fosfor in de bodem. Aanvoer van water uit de omgeving betekent aanvoer van voedselrijk water. Afgraven kan de voedselbeschikbaarheid verlagen maar leidt eveneens tot verlies van de huidige vegetatie, de zaadbank en creëert maagdelijke situaties waarin stekende insecten juist de eerste jaren uitstekende broedplaatsen kunnen vinden.

De conclusie luidt dat de kans dat het studiegebied Westelijke Langstraat met de voorgenomen herinrichting leidt tot overlast van stekende insecten aannemelijk groot is tenzij er in wordt geslaagd door peilbeheer en watersturing een hydrologisch stabiele situatie te laten ontstaan waarbij voedselarme kwel de boventoon voert en de waterpeilen in zomer en in winter weinig gaan fluctueren. Met andere woorden dat geen tijdelijk water in het voorjaar of na zware regenbuien in de zomer op maaiveld gedurende weken achterblijft. Daarnaast kan in de $1^{\mathrm{e}}$ jaren meer overlast optreden, totdat ecosysteem weer ontwikkeld is, waarbij natuurlijke predatoren van stekende insecten algemener zullen voorkomen.

Monitoring zou dit verschijnsel kunnen vastleggen en zou ook helpen bij het gedetailleerd waterbeheer doordat bij larvenontwikkeling snel kan worden opgetreden.

\subsection{Aanbevelingen}


De afstand tot bewoning is zo klein dat indien larven in hogere aantallen tot ontwikkeling komen ze tot overlast zullen leiden. Zorg er daarom voor dat de aantallen zich ontwikkelende larven van stekende insecten zo laag mogelijk wordt. Hiervoor moeten de volgende punten aandacht krijgen:

- Zorg ervoor dat met gedetailleerd peilbeheer de waterpeilen stabieler worden, water op maaiveld in de loop van april over grotere oppervlakken is verdwenen en ook in de zomer niet tijdelijk voorkomt. Anders zal overlast van stekende insecten gaan optreden.

- Zorg daarnaast ervoor dat er zo min mogelijk voedselrijk water in het gebied wordt ingelaten. Hiermee wordt de kans op overlast van stekende insecten verder verminderd.

- Zorg er ook voor dat volwassen dieren vooral hun toevlucht kunnen zoeken in het gebied zelf, bijvoorbeeld door gericht bosschages te laten staan of aan te brengen en door het bemoeilijken van verspreiding door open corridors van zeer korte vegetatie of open water aan te brengen. Hierdoor wordt de kans op overlast van stekende insecten verder verkleind.

- $\quad$ Met gericht beheer kunnen de aantallen stekende insecten nog verder verlaagd worden zoals door 1 ) het maaien van gebieden die bedoeld zijn om als barrière te fungeren tegen de verspreiding van volwassen dieren, 2) het niet of ondiep plaggen om te natte gebieden te voorkomen, en 3 ) het niet begrazen van natte gebieden om vorming van kleine depressies die weer als broedplaatsen gaan fungeren, te voorkomen 


\section{Literatuur}

Nieuwkamer R.L.J., N.C. van der Zijden \& A.R. van Driel (2019). Westelijke Langstraat. Milieueffectrapport. Provincie Noord-Brabant. Provincie Noord-Brabant, Witteveen \& Bos 103362-3/19-004.462. https://www.westelijkelangstraat.nl/

Provincie Noord-Brabant (2017). Concept Notitie reikwijdte en detailniveau voor het milieueffectrapport Westelijke Langstraat ten behoeve van advies en inspraak, 29 mei 2017.

Verdonschot P.F.M. \& Besse-Lototskaya A. (2012). Leidraad Risicomanagement Overlast Steekmuggen en Knutten: Toelichting op de Leidraad. Alterra-rapport 2298, 59 pp.

Verdonschot P.F.M. \& Besse-Lototskaya A.A. (2014). Flight distance of mosquitoes (Culicidae): A metadata analysis to support the management of barrier zones around rewetted and newly constructed wetlands. Limnologica 45 (2014) 69- 79. 